\title{
Doğu Karadeniz Bölgesi Kirkitli Dokumalarında Geometrik ve Bitkisel Motiflerden Örnekler*
}

\section{Geometric and Herbal Motifs Used in Kirkit Textiles from the Eastern Black Sea Region}

\section{Keziban Selçuk ${ }^{* *}$ (1), Hüseyin Yurttaş ${ }^{* * *}$ (1)}

Öz

Geçmişten günümüze kadar insanoğlu hayatını sürdürmek ve ihtiyacını karşılamak üzere tekstil ürünleri geliştirmiş, dokumaların yüzeylerini çeşitli biçimde süslemiştir. Orta Asya'dan bugüne âdeta bir motif birikimi oluşmuş ve dokumalarda tekrarlanarak varlığını devam ettirmiştir. İnsanlar Tanrıya inanç ve bağlılıklarını çeşitli şekillerde belirtmek amacıyla yazılar ve semboller kullanmışlardır. Semboller, düşüncelerini dokumalar üzerine yansıtan dokuyucunun aynı zamanda dili olmuştur.

Doğu Karadeniz Bölgesi, günlük hayatta ihtiyaç doğrultusunda üretilen hem kullanım açısından hem de üzerindeki motifleri bakımından zengin çeşitlilik gösteren geleneksel dokumaların yapıldığı coğrafyalardan biridir. Hayatı kolaylaştıran ürünler; yer yaygısı, yolluk, sedir örtüsü, yastık, duvar sergisi, çuval, çul, beşik örtüsü, ip, heybe, çanta gibi halı ve düz dokumalar ile peşkir, peştamal, omuz şalı, ehram olarak kullanılan kumaş dokumalardır. Dokumalar üzerinde yer alan motiflerin zengin bir kültür varlığını yansıttığı ve geometrik, bitkisel, figürlü, sembolik motifler ile yazı ve tasvirlerin kullanıldı̆ı görülmektedir. Ancak gelişen teknoloji ve hayat kültürünün değişmesiyle birlikte günümüzde bu dokumaların giderek azaldığı ve kaybolmak üzere olduğu bir gerçektir. Çalışmada Doğu Karadeniz Bölgesi dokumalarında görülen geometrik ve bitkisel motifler ele alınmış, bölgede tespit edilen ürünler fotoğraflanarak belgelenmiş, üzerlerinde bulunan motifler incelenmiştir. Dokumalarda yer alan geometrik motifler yıldız, altıgen, sekizgen, eşkenar dörtgen, kare, bitkisel motifler ise çiçek, yaprak, dal, hayat ağacı ve pıtraktır.

Anahtar Kelimeler

Motif, geometrik motif, bitkisel motif, Doğu Karadeniz Bölgesi dokumaları

\section{Abstract}

Human beings have been creating textile products to meet their survival needs and to enhance their lives, and they have decorated the surfaces of these fabrics in various ways. These motifs have long shown great richness, and this richness lives on in contemporary weaving. People have used writing and symbolic expression to represent their faith and devotion to God in many ways. These symbols have become the language of weavers who have reflected their thought in their weaving.

* Bu makale Atatürk Üniversitesi, Sosyal Bilimler Enstitüsü Türk İslam Sanatları Anabilim Dalı Doktora Programı'nda Prof. Dr. Hüseyin Yurttaş danışmanlığında Keziban Selçuk tarafindan hazırlanan “Doğu Karadeniz Bölgesi Dokumaları” başlıklı doktora tezinden üretilmiştir.

** Sorumlu Yazar: Keziban Selçuk (Arş. Gör. Dr.), Atatürk Üniversitesi, Oltu Meslek Yüksekokulu, Erzurum, Türkiye. E-posta: kselcuk@atauni.edu.tr ORCID: 0000-0002-3460-4457

*** Hüseyin Yurttaş (Prof. Dr.), Atatürk Üniversitesi, Edebiyat Fakültesi, Sanat Tarihi Bölümü, Erzurum, Türkiye. E-posta: hyurttas@atauni.edu.tr ORCID: 0000-0002-3968-5321

Atıf: Selcuk, Keziban ve Yurttas, Huseyin. “Doğu Karadeniz Bölgesi Kirkitli Dokumalarında Geometrik ve Bitkisel Motiflerden Örnekler." Art-Sanat, 15(2021): 287-315. https://doi.org/10.26650/artsanat.2021.15.0012 
The Eastern Black Sea Region of Turkey features traditional weaving in response to lifestyle needs, which are rich in both use and motif. Carpets and plain weavings such as floor mats, runners, cedar covers, pillows, wall exhibitions, sacks, sackcloth, cradle covers, ropes, saddlebags, bags, as well as cloth fabrics used as napkins, loincloths, shawls, and ihram, are made to ease life's burdens. The motifs on the weavings show rich cultural, geometric, floral, figural patterns, and symbolic motifs, with writing and image depictions. However, it is a fact these weavings are gradually becoming less common and are disappearing day by day because of developing technology and lifestyle. In this study, geometric and herbal motifs commonly seen in the Eastern Black Sea Region weavings were investigated, the products obtained were photographed and documented and the motifs on them were examined.

The geometric motifs found in the weavings include the star, hexagon, octagon, rhombus, and square; the plant motifs shown include the flower, leaf, branch, tree of life, and pitrak.

Keywords

Motifs, geometric motif, floral motif, East Black Sea Region weavings

\section{Extended Summary}

In the Dictionary of the Turkish Language Association, a motif is described as a decorative element that can be seen either as an ornament or as a separate entity. These are generally small elements that go together to make up an entire composition and may contain messages. Motifs are seen in all types of handcrafts and have a large part to play in weaving as well. These are elements in the language of the weaver that develop and survive across time, from the past to the present. Geometric, floral, figured (animal/human), symbolic, pictorial, and writing motifs are used in traditional weavings. In this study, the geometrical and floral motifs of Eastern Black Sea Region weavings are discussed.

Geometrical motifs are lovingly incorporated in artworks and in other arts. These motifs consist of stars, hexagons, octagons, triangles, rhombuses, squares, and quadrilaterals. The floral motifs are basic elements in the Turkish decorative arts, and flowers, leaves, twig, fruits, and trees are sometimes presented in the same (naturalist) form in which they exist in nature, and they sometimes appear in a stylized manner.

A field study was carried out in the Eastern Black Sea Region to obtain access to the approach to weaving used there, and carpets and plain weavings were photographed in detail. Information was acquired face-to-face interviews with weavers or those knowledgeable about weaving or who own weavings. Motifs were photographed, analyzed, and isolated for reproduction.

Field study has shown that traditional weaving is still being produced in the Eastern Black Sea Region. The geometric motifs seen in these weavings include stars, rhombuses, and octagons. The rhombus and octagon shapes are generally used as medallions at the base of the weavings.

The motifs used are symbols from folk systems of belief, such as the stars, the moon, and the sun. The motif is described as the symbol of the sky and eternity; 
it is loved and finds use in different forms in stone, wood, tile, metal, textile, weaving, and many other handicrafts. The Anatolian people believed that there has always been a link between the stars and human destiny. The star motif has long been used in weavings made in Anatolia, and it is very common in Seljuk carpets. The star motif can be seen in $13^{\text {th }}$ century carpets in weavings in the Eastern Black Sea Region. The star motif is popularly used in the carpet in F. 8 in Bayburt and in the rug in F. 4.

Hexagonal, octagonal, rhomboid, and square forms are seen in surface decorations in Turkish handcrafts, where they are often used as decorative elements that are applied to create certain areas on the surfaces. These geometric forms are also used in weavings, and they appear in medallions with hexagons, octagons, and rhombuses in carpets and plain weaves. Medallions consisting of rhombus and octagons are used on weaving floors in the region. A medallion consisting of six octagons lined up side by side lined up side by side is found on the bottom of the carpet in F. 10, found in the Şavşat district of Artvin. Medallions woven by rhombuses placed on top of each other form the bottom of the kilim pillow in F. 13 and are identified in Bayburt.

It has been seen that the plant motifs in these weavings generally include those of the flower, branch, leaf, tree of life, and velvet. The tree of life symbolizes that the underground, the earth, and the sky are always connected with each other, and the velvet motif is considered to represent abundance and fertility.

Floral motifs began to be seen in Turkish carpet art following the greater influence of Iran in the $16^{\text {th }}$ century, and the richness of the motifs acquired was created by using natural motifs, such as those of the carnation, tulip, hyacinth, chamomile, rose, marshmallow flower, and peony, together with stylized plant motifs such as those of insects, buds, daggers, and leaves. The floral motifs used in the carpet panel found in F. 16 identified in Artvin are woven together in a naturalistic manner. It has been concluded that floral motifs are frequently used in plain weavings, especially in Artvin and Bayburt. In the rug wall exhibition in F. 18, F. 21, F. 25, it can be seen that flower branches and leaves are used in the ground spread. The flower motifs draw attention in the prayer rug in F. 28.

The tree of life, a motif that is commonly seen among the herbal motifs, creates a vertical symbolism of life that is constantly developing and rising to heaven. The most important feature of the tree of life, located in the center of the world, is, as mentioned, the connection it makes among the underground, the earth, and the sky. The oldest carpets that use the tree of life motifs are animal figured carpets that date to the $14^{\text {th }}$ and $15^{\text {th }}$ centuries. It has been determined that the tree of life was used in plain weavings made in Kocabey Village, Şavşat district, Artvin Province, within the scope of the study. On the red floor of the wall exhibition discovered in Artvin and 
located in F. 31, bunches of flowers can be seen to emerge from ten vases colored blue and orange in three rows.

One motif seen in the weavings is that of velvet, which represents abundance and fertility and is also used to destroy evil. In the field study conducted in the region, the velvet motif was found included in the weavings. It is seen that the rug floor mat in F. 33 in Bayburt, the Palaz rug in F. 36 in Giresun, and the zilli rug in F. 39 in Gümüşhane are popularly used versions of ground mats.

It can be understood that the motifs used in the weavings in the field studies of ancient rug weaving in Central Asia continue up to the weaving of today and bear the traces of past cultures. 


\section{Giriş}

Dokumacılık, dünyada insanın varoluşuyla birlikte giyinme, örtünme, soğuktan korunma gibi birtakım ihtiyaçlar sonucunda ortaya çıkmış ve zamanla hem dokuma tekniğiyle hem de üzerine işlenen motiflerin içerdiği anlamlarıyla tarihin kayıtlı vesikaları hâline gelmiştir.

Dokumacılığın Anadolu'da da tarihî bir geçmişi vardır. Anadolu'da yürütülen arkeolojik çalışmalarda neolitik dönemin var olduğu ortaya konmuş, bu dönemde dokumaların yapıldığını gösteren iplik büküm aletleri ve tezgâh ağırlıklarının varlığına ek olarak korunan tekstil kalıntıları dokuma teknikleri hakkında önemli bilgiler ortaya çıkarmıştır. Anadolu'da ortaya çıkarılan ve M. Ö. 6000 yıllarına tarihlendirilen en eski dokumalardan biri, 1962 yılında yapılan kazılarda Çatalhöyük'te bulunmuştur' ${ }^{1}$. Gömütlerde kumaş parçalarının korunmuş olduğu görülmektedir ${ }^{2}$. Konya'nın Çumra ilçesi sınırlarındaki neolitik yerleşim yeri olan Çatalhöyük'teki yanmış bir evin tabanında bebek iskeleti üzerinde bulunan 9000 yıllık bir dokuma, dünyanın ilk keten kumaş parçasıdır ${ }^{3}$.

Rudenko tarafından 1949 yılında Türklerin anayurdu Orta Asya'da Altay Dağları eteklerinde yer alan II. ve V. Pazırık kurganlarında yapılan araştırma ve kazı çalışmaları sonucunda bölgedeki en eski halı ve havsız kirkitli dokumalar bulunmuştur. Dokumaların doğal boyalarla boyanmış yün ipliğiyle yapıldığı gözlemlenmiştir. Bölgede kökboya (Rubia Tinctorum L.) bitkisinin yetiştiği bilinmektedir. Kazılardan çıkarılan boya kaplarında mavi renkli boyanın izlerine rastlanmıştır. Orta Asya'da yaşayan Oğuz boyları göç ederek Anadolu'ya yerleşmeye başlamış ve aynı hayat kültürlerini geldikleri yerlerde yaşayan toplumların kültürleriyle etkileşimi sonucunda daha da zenginleştirerek devam ettirmişlerdir. Hareketlilik Doğu Karadeniz Bölgesi’nde de yaşanmış ve Oğuzların bir kolu olan Çepni Türkmenleri ilk önce Sinop başta olmak üzere Anadolu topraklarına gelerek varlıklarını ve dokuma geleneklerini sürdürmüşlerdir ${ }^{5}$. Türk toplumunun hayatında hayvancılık her zaman önemini korumuş hem beslenmek hem de yününden faydalanmak için insanlığın vazgeçilmezi olmuştur. Besledikleri koyun ve keçilerinin yünlerini bükerek iplik hâline getirmişler, elde ettikleri iplikleri dokuyarak giyim, yaygı örtü ve benzeri biçimde kullanmışlardır. Koyun ve keçi yününün kahverengi, gri ve siyah olanları doğal renkleriyle, beyaz yünler ise doğal veya çeşitli renklerde boyanarak dokumalarda kullanılmaktadır. Bölgede yapılan

1 Gürkan Ergün, "Weaving in Anatolia in Prehistoric Period", IV. International Multidisciplinary Congress of Eurasia (27-30 Nisan 2017) (Barcelona/İspanya, 2017), 120, erişim 10 Ağustos 2019, https://www.imcofe.org/2017/barcelona/Download/imcofebarcelonafulltext2017.pdf.

2 Ian Hodder, Çatalhöyük Leoparın Öyküsü, çev. Dilek Şendil (İstanbul: Yapı Kredi Yayınları, 2017), 23.

3 Erişim 18 Aralık 2019, https://www.tekstilbilgi.net/dunyanin-en-eski-kumaslari.html,

4 Oktay Aslanapa, Türk Halı Sanatının Bin Yllı (İstanbul: İnkılap Kitabevi, 2005), 19.

5 Abdullah Gülay, Ağasar Çepni Kültürü Geyikli Folklor- İnceleme-Araştırma (İstanbul: Geyikli Belediyesi Kültür Yayınlar1-1, 2001), 27. 
yünlü dokumalarda koyun yünü daha fazla tercih edilmektedir'. ${ }^{6}$ Orta Asya'dan gelen Türkmenler, yerleştikleri Doğu Karadeniz Bölgesi'nde de dokuma geleneklerini ve kullandıkları motiflerini Anadolu'da var olan dokuma geleneğiyle birlikte sürdürmüşlerdir.

2018-2019 yılında alan araştırması kapsamında Artvin, Bayburt, Giresun, Gümüşhane, Rize ve Trabzon il, ilçe ve bazı köylerine seyahatler düzenlenmiş, günümüzde bölgede dokumayı yapan, bilen kişilerle yüz yüze görüşmeler gerçekleştirilmiş, nerelerde dokumaların bulunabileceği konusunda bilgiler alınmış ve veriler doğrultusunda geleneksel dokumalara ulaşılmaya çalış1 1 mıştır ${ }^{7}$. Dokumalarda zengin bir motif kültürünün olduğu gözlemlenmiştir. Çalışmada motif konusuna değinilerek, Doğu Karadeniz Bölgesi'nde tespit edilen dokumalarda yer alan geometrik ve bitkisel motifler ele alınmıştır.

Türk Dil Kurumu Sözlüğünde motif, yan yana gelerek bir bezeme işini oluşturan ve kendi başlarına birer birlik olan ögelerden her biri olarak ifade edilmiştir. Diğer bir deyişle tekstil, ahşap, taş, çini, metal, ahşap, tezhip, minyatür ve benzeri el sanatlarında yer alan ve kompozisyonu oluşturmak için kullanılan her bir ögeye "motif" denilmektedir. Motif ve desen terimleri "oyu", "organtı", "yangıç", "yangış", "yanış", "nanış", "nakış", “desen”, "model”, "örnek", "tabak”, "su” gibi isimlerle de anılmaktadır.

Geleneksel Türk sanatlarında yer alan motifler toplum kültürünün bir yansımas1 olarak kullanıldıkları yüzeylerde anlatım dili olarak ifade bulmuştur. Aydın Uğurlu,

"Motif dili görsel sanatlar arasında en çok kullanılan dildir. Bu öyle güçlü bir dil ki ne zaman kavramı tanır ne mekân. Faklı zamanlarda, ayrı ayrı ülkelerde bambaşka koşullar içinde yaşadıkları halde motif dili insanı şaşırtan bir tempo ile toplumların ortak dili olmuş, mimari, heykel, din ve dil değişmiş fakat motif her zaman özelliğini korumuştur”"

ifadesiyle motiflerin önemine vurgu yapmıştır. Dokumalarda yer alan motifler de dokuyucu kadının duygu, düşünce, gelenek, hayat kültürü ve inançlarını ifade eden semboller hâline gelmiştir. Dokuma desenlerini meydana getirmek için sadece dokuma tekniğinin bilinmesi yeterli değildir. Bunun yanında toplumda sembolik anlamların farkındalığı ve motiflerin estetik, derinlik ve kültürel değerlerinin de bilinmesi gerekmektedir. Selçuklu Dönemi’nden itibaren Yörük ve Türkmen kadınlarının dokudukları halı ve kilimler işlevselliklerinin yanı sıra motif ve renkleriyle de dikkat çekicidir. Geleneksel dokumaların etrafı "bordür” adı verilen ve çeşitli motiflerle süslenen ke-

6 Mustafa Reşat Sümerkan, Trabzon Yöresi Geleneksel El Sanatları (Trabzon: Serander Yayınları, 2008$), 113$.

7 Finansal Destek: Yazar bu çalışma için finansal destek almamıştır.

8 Bekir Deniz, “Anadolu-Türk Halı ve Düz Dokuma Yaygılarında Bazı Motiflerin İsimlendirilmesi,” Akdeniz Sanat Dergisi 3/5 (2010), 53; Ali Akar ve Mustafa Karataş, "Milas Halı ve Kilimleri İçin Kullanılan Yanış (Motif) Adlarının Dil İncelemesi,” Arış 5 (Mart 2011), 7.

9 Aydın Uğurlu, “Anadolu Dokumalarında Motif Felsefesi," Tekstil ve Mühendis 5 /26, (Nisan 1991), 78, erişim10 Kasım 2020, https://dergipark.org.tr/tr/pub/teksmuh/issue/12908/156221. 
narsuyu ile çevrilmekte ve zemin kısmı sınırlanmaktadır. Zemin, dokuyucu kadın için kutsal sayılmış, motif ve renkler itinayla seçilip dokunmuştur ${ }^{10}$.

Dokumacılık insanlığın varoluşundan itibaren varlığını devam ettirerek günümüze kadar gelişimini sürdürmüş ve üzerinde yer alan motifleriyle sanatsal bir boyut kazanmıştır. Dokumacılığa ilk önce hayvan postunun örnek teşkil ettiği ve hayvan postu motifinin zamanla soyutlaşarak bazı halılarda göbek motifi olarak kullanıldığı düşünülmektedir.

Güran Erbek'e göre, motifler, dokuyan kişilerin çevreleriyle iletişim kurmak için kullandıkları dilin biçimsel ögeleridir ${ }^{11}$. İnsanlar Tanrıya inanç ve bağlılıklarını çeşitli şekillerde belirtmek amacıyla yazılar ve semboller kullanmışlar, aynı düşüncelerini dokumalar üzerine de yansıtmışlardır. Dokumalar üzerindeki motifleri dokuyan kişilerin Anadolu'ya gelmeden önce nerelerde yaşadığını, hangi kültür çevreleriyle alışverişte bulunduklarını da ortaya koymaktadır. Kare, eşkenar dörtgen, yıldız, çarkıfelek ve benzeri motifleri Orta Asya'da kullanan Türk toplulukları Anadolu'ya geldiklerinde de devam ettirmişlerdir ${ }^{12}$.

\section{Doğu Karadeniz Bölgesi Dokumaları}

Doğu Karadeniz Bölgesi'nde yapılan dokumalar Orta Asya'dan göçler vasıtasıyla bu topraklara gelip yerleşen Türk topluluklarının bölgede yaşayan toplumların sanatından etkilenip sentezledikleri yeni ögeleri de katarak sürdürdüğü geleneğin devamı niteliğindedir. Bölgede yapılan dokumalar teknik, kompozisyon, motif, kullanılan tezgâh ve malzemesiyle benzer özellikler göstermektedir. Bölge halk1nın baharın gelmesiyle birlikte yaylaya göç etme geleneği hâlâ devam etmektedir. Mayıs-Eylül ayları arasında yaylada kalan yöre insanı, yolculuk boyunca eşyalarını taşımak amacıyla çuval ve heybe, ip (kolan, bağ, dırmaç), soğuk ve yağmurdan korunmak, hayvanlarının üzerini örtmek için çul olarak adlandırılan örtüler, gittikleri bölgede kalacakları evlerde, yaygı olarak kullanmak üzere halı ve havsız kirkitli dokumalardan oluşan yer yaygısı, sedir yaygısı, duvar sergisi, yastık gibi ürünlerden faydalanmaktadırlar. Dokumaların insan hayatında önemli ihtiyaçlardan biri olması nedeniyle, kadınlar tezgâh ve dokumada kullandıkları malzemeleri gittikleri yere götürüp, tezgâhlarını kurmuş ve boş kaldıkları zamanlarında halı, kilim ve kumaş gibi dokumalar yapmış, ihtiyaç fazlasını da satarak geçimlerini devam ettirmek için kazanca dönüştürmüşlerdir ${ }^{13}$.

10 Aydın Uğurlu ve Servet Senem Uğurlu, “Anadolu Kirkitli Halk Dokumalarında Felsefi Yorumlara Açık Bazı Motifler," II. Uluslararası Felsefe, Eğitim, Sanat ve Bilim Tarihi Sempozyumu, (03-07 Mayls), (Muğla: Muğla Sttkı Kocaman Üniversitesi Atatürk Kültür Merkezi, 2017), 1470.

11 Mine Erbek, Çatalhöyük'ten Günümüze Anadolu Motifleri (Ankara: T.C. Kültür Bakanlığı, 2002), 4.

12 Beyhan Karamağaralı, "Türk Halı Sanatındaki Motiflerin Yorumu Üzerine," Arış 3 (Aralık 1997), 30.

13 Keziban Selçuk, "Doğu Karadeniz Bölgesi Dokumaları” (Doktora tezi, Atatürk Üniversitesi, 2020), 790. 
Doğu Karadeniz Bölgesi'nde namazlık, yolluk, yer yaygısı, duvar sergisi, divan yaygısı ve yastıklar, heybe ve çanta, çuval, çul, cicim, beşik örtüsü, ip (bağ, dırmaç), peştamal, peşkir (havlu), ehram ve omuz şalı gibi dokumaların yapıldığı tespit edilmiştir. Geçmişten günümüze gelişerek varlığını devam ettiren ancak günümüzde kaybolmaya yüz tutmuş geleneksel el sanatının gelecek nesillere aktarılması için çeşitli projeler hazırlanarak dokumaların gerçekleştirildiği görülmektedir. Yapılan alan araştırmasında, bölgenin iç kesimlerinde yün ve kıl, sahildeki yerleşim alanlarında ise pamuk, kenevir ve az da olsa ipekli dokumaların yapıldığı tespit edilmiştir. Anadolu'ya gelen boyların dokuma kültürünün bu topraklarda var olan dokuma geleneğiyle birlikte devam ettiği, dokuma öncesi ve esnasında yapılan işlemlerin benzer olduğu görülmektedir.

Ülkemizde her yörenin beslediği koyunun cinsi farkl11ık göstermekte ve bulunduğu bölgenin coğrafi şartları hayvan yetiştiriciliğine etki etmektedir. Doğu Karadeniz Bölgesi'nde yetiştirilen koyunlar engebeli arazi şartlarına uyum göstermiş olan ve yörede "Çepni koyunu" adı verilen bir cinstirr". Çepni koyunlarının yünlerinin kırkı$\mathrm{m} ı$ ile elde edilen elyafın yıkanması, taranması, iğ (teşi) denilen iplik bükme aletiyle bükülerek ipliğin elde edilmesi işlemi, hep geleneksel yöntemlerle yapılmaktadır. Eğrilen iplikler bölgede genellikle "alemidi-alemit" olarak bilinen çıkrık yardımıyla çileler hâline getirilerek boyamaya hazırlanmaktadır. Çıkrık, iplik eğirme işlemini mekanize etmenin ilk aşaması olan iği yatay olarak yerleştirip büyük bir çark tarafindan elle çevrilebilmesine imkân sağlamaktadır ${ }^{15}$. İpliklerin renklendirilmesinde ise bitkisel boyalardan faydalanılmış ve genellikle boyama işini yapan ustaların olduğu, boyamayı bu kişilerin yaptığı, kaynak kişiler tarafından ifade edilmiştir. Yöre insanının ifadelerinden geçmişte doğal boyama işlemini gerçekleştiren "boyacı" adı verilen kişilerin bulunduğu ve "boyacılık" mesleğinin olduğu anlaşılmaktadır. Boyamanın geleneksel yöntemlerle yapıldığ 1 ve $1 \mathrm{~kg}$ yün ipliğiyle $1 \mathrm{~kg}$ boya bitkisinin birlikte kaynatıldığı, bölgede yaşayan ve eskiden boya işini yapan ya da bilenler tarafindan verilen bilgilerden anlaşılmaktadır. Ancak günümüzde kimyasal boyalarla ipliklerin boyandığ 1 görülmektedir. Boyama işleminin ardından iplikler çıkrık yardımıyla yörede "kalam/ masura" adı verilen aletlere sarılarak kullanım için hazırlanmaktadır. Halı ve havsız kirkitli dokumalarda yörede "şal tezgâhı" adı verilen yatay tezgâh, germe tezgâh, sarma tezgâh kullanılırken, kumaş dokumalarda ise kamçılı tezgâhlardan faydalanılmaktadır (G.1, G. 2, G. 3) ${ }^{16}$. Bu tezgâhlarda mekik el ile değil kamçı ile atılmaktadır. Kamçılı tezgâhlar diğer tezgâhlara göre daha hızlı ve verimlidir ${ }^{17}$.

14 Nazım Kuruca ve Muammer Ak, "Doğu Karadeniz Bölgesinde Konargöçer Hayata Dair Uygulamalar: Giresun Örneği," UKDA (A. Haluk Dursun Anısına Uluslararası Türk Kültürü Sempozyumu Dil-Tarih-Coğrafya) 6-8 Aralık 2019 Ed. Fahri Temizyürek (Ankara: Asos Yayınevi, 2019), 788, erişim 20 Aralık 2020, http:// giramer.giresun.edu.tr/Files/ckFiles/giramer-giresun-edu-tr/Makaleler/Muammer\%20AK.pdf,

15 Rize El Sanatları (Rize: Rize Halk Eğitim Merkez Müdürlüğü Yayınları, 2004), 46.

16 Selçuk, Doğu Karadeniz Bölgesi Dokumaları, 791.

17 Şahin Yüksel Yağan, Türk El Dokumacıllğg (İstanbul: Türkiye İş Bankası Kültür Yayınları, 1978), 76. 


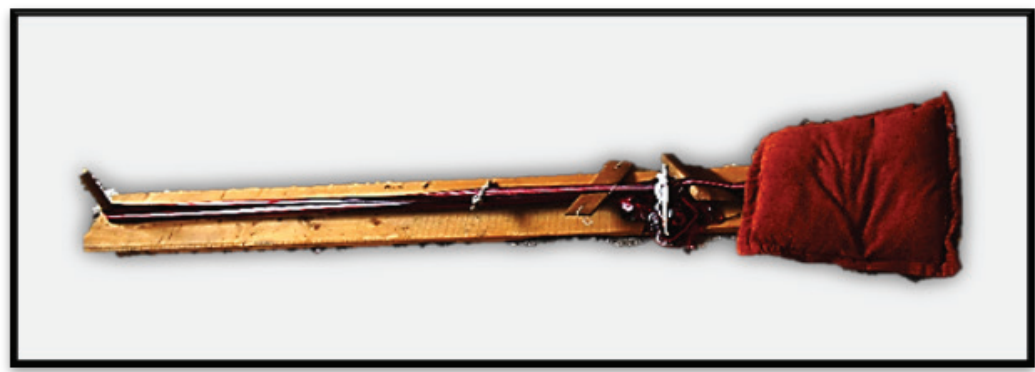

G. 1: Şal Tezgâhı (Trabzon ili Şalpazarı İlçesi Halk Eğitim Merkezi) (Keziban Selçuk, 2019)
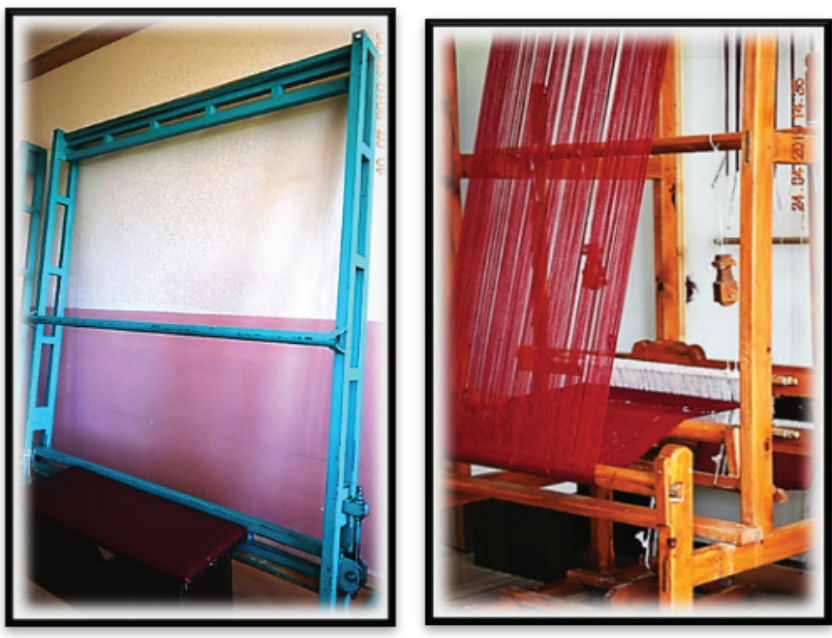

G. 2: Germe Tezgâh (Gümüşhane ili Kelkit ilçesi Halk Eğitim Merkezi) (Keziban Selçuk, 2019)

G. 3: Kamçılı Tezgâh (Bayburt Üniversitesi Baberti Külliyesi Dokuma Atölyesi) (Keziban Selçuk, 2019)

“Doğu Karadeniz Bölgesi dokumaları” üzerine yapılan çalışma kapsamında literatür taramasında bölge dokumacılığıyla ilgili yeterince araştırmanın ortaya konmadığı gözlemlenmiştir. Artvin, Bayburt, Giresun, Gümüşhane, Trabzon ve Rize il, ilçe ve bazı köylerinde yapılan alan araştırması sonucunda bulunan dokumaların fotoğrafları çekilerek bunlar üzerinde kullanılan motiflerin teknik çizimleri yapılmış, kaynak kişilerden bilgiler edinilmiştir. Doğu Karadeniz Bölgesi’nde dokumacılığın eskisi kadar yapılmadığı ve yok olmaya yüz tuttuğu görüşülen kaynak kişiler tarafından ifade edilmektedir. Geleneksel dokumalarımızın literatüre kazandırılması amacıyla yapılan araştırma sonucunda tespit edilen dokumalarda geometrik, bitkisel, figürlü (hayvan/insan), sembolik, yazı ve tasvir (nesne), resim gibi motiflerin kullanıldığ görülmektedir. 


\section{Dokumalarda Kullanılan Motifler}

Doğu Karadeniz Bölgesi'ndeki dokumalarda yer alan motiflerin oldukça zengin olduğu yapılan alan araştırmalarında görülmektedir. Geometrik motifler yıldız, eşkenar dörtgen, dörtgen, kare; bitkisel motifler hayat ağacı, pıtrak, çiçek, yaprak ve dal; figürlü (hayvan/insan) motifler akrep, ejder, kuş, insan, yılan, kazayağı, elibelinde, kurbağacık; sembolik motifler ibrik, bereket, göz, kurtağzı-kurtizi, muska, sand1kl1, suyolu, tarak, küpe, çengel, çarkıfelek, yaba, kandildir. Bu motiflerin yanısıra bazı dokumalarda yazı ve tasvirlerin kullanıldı̆̆ı gözlemlenmiştir. Bu makalede, konunun geniş ve kapsamlı olması nedeniyle sadece geometrik ve bitkisel motifler ele alınıp, Doğu Karadeniz Bölgesi’nde bulunan dokuma örnekleriyle desteklenecektir.

\section{1. Geometrik Motifler}

Geometrik motifler, bilinen en eski süsleme öğelerinden olup, el sanatlarında ve diğer sanatlarda sevilerek kullanılmıştır. Bu motifleri, yıldız, altıgen, sekizgen, üçgen, eşkenar dörtgen, kare, dörtgen gibi geometrik şekiller oluşturmaktadır ${ }^{18}$.

Doğu Karadeniz Bölgesi’ndeki dokumaların büyük bir çoğunluğunda geometrik motifler yer almaktadır. Geometrik motiflerden biri olan Yıldız motifi dokumaların genellikle zemininde veya bordüründe yan yana sıralanmış biçimde görülmektedir. Dokumalarda daha çok sekiz kollu yıldız motifinin kullanıldığı tespit edilmiştir. Geometrik motiflerden eşkenar dörtgen, kare, altıgen, sekizgen formların ise genellikle dokumanın zemininde ana motif olarak yer aldığı yapılan alan araştırmasından anlaşılmaktadır.

\subsubsection{Yıldız Motifi}

Yıldız, ay ve güneş gibi halk inanışlarında var olan bir semboldür. Motif, taş, ahşap, çini, maden, tekstil, dokuma ve benzeri daha birçok el sanatında farklı biçimlerde sevilerek kullanılmaktadır ${ }^{19}$. Yıldız motifine köşe sayısına göre çeşitli anlamlar yüklenmiştir. Altı köşeli yıldız İslam dünyasında "Mühr-ü Süleyman” adıyla bilinen Hz. Süleyman'ın mührüdür. Mühür Musevilerde "Davut Yıldızı”, İsevilerde "Devit Yıld1zı" olarak adlandırılmaktadır ${ }^{20}$. Selçuklu yıldızı olarak da bilinen sekiz köşeli yıldız, iki karenin çapraz şekilde üst üste gelmesinden meydana gelmektedir. Bu kareler Tanrının yer ve gök güçlerine, yani dört köşe-sekiz bucağa, hâkim olmasını sembolize etmektedir ${ }^{21}$. Doğu Karadeniz Bölgesi’nde bulunan havlı ve havsız kirkitli dokumalarda sekiz kollu yıldız motifinin yer aldığı ve sevilerek kullanıldığ́ gözlemlenmiştir.

18 Haldun Özkan, Sanat Tarihine Giriş Ders Notları (Erzurum: Zafer Medya, 2017), 154.

19 Hakan Çiloğlu, “Türk Halı Sanatı Kompozisyonlarında Hayat ve Zaman Kavramları,” Atatürk Üniversitesi Güzel Sanatlar Enstitüsü Dergisi, 43 (2019), 205.

20 İskender Pala, "Mühr-i Süleyman”, TDV İslam Ansiklopedisi, c.31, (İstanbul: Türkiye Diyanet Vakfı Yayınlar1, 2006), 526.

21 Aysen Soysaldı, “Türklerde Yıldız Motifi ve Teke Yöresi Yıldızlı Zili (Burdur Müzesi) Örnekleri,” Maddi Kültür, 9. Milletlerarası Türk Halk Kültürü Kongresi (Ankara: T.C. Kültür ve Turizm Bakanlığı Araştırma ve Eğitim Genel Müdürlüğü, 2017), 427. 
Kilimlerde kullanılan altı köşeli yıldızın merkezinde, denge, gece-gündüz, YinYang motifi bulunmaktadır. Sekiz köşeli yıldız ise genellikle zili ve cicim dokumalarda kullanılmakta ve motifin merkezine göz motifi yerleştirilerek uygulanmaktadır ${ }^{22}$.

Alan araştırması yapılan illerden biri olan Bayburt ili Demirözü ilçesine bağlı Beşpınar Beldesi'nde, 20. yüzyıla ait eski bir halıdan kalan parça tespit edilmiştir (G. 4, G. 5). Türk düğümüyle dokunmuş olan halının kırmızı renkli zemininde beş adet sarı, gri, açık ve koyu kahverengi, sarı renkli kare alan içine sekiz kollu yıldız motifi üst üste sıralanmıştır (G. 6). Yıldız motifinin içinde ise göz motifinin yer aldı̆̆ı görülmektedir. Halının koyu kahverengi zemine sahip geniş bordüründe de yine sekiz kollu yıldız motiflerinin sıralandığı görülmektedir. Sekiz kollu yıldız, göçebe kültüründe geceleri yön göstermesi bakımından önemli motifler arasında yer almaktadır. Bayburt ili Demirözü ilçesine bağlı Beşpınar Beldesi’nde tespit edilen bu halı parçasında kullanılan yıldız motifi de aynı geleneğin devam ettiğini göstermesi bakımından önemlidir. Dokumada kullanılan iplikler bitkisel boyalarla boyanmıştır.

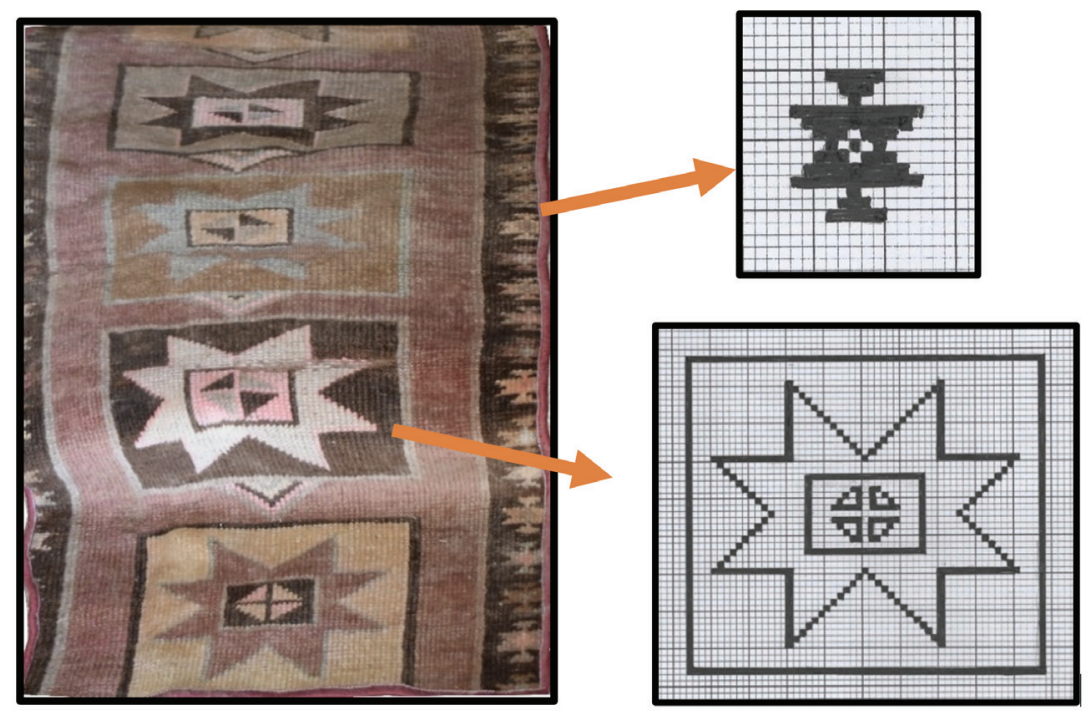

G. 4: Yolluk, 20. Yüzyıl (Bayburt İli-Demirözü İlçesi Beşpınar Beldesi- Kenan Yavuz Kültür Evi) (Keziban Selçuk, 2019)

G. 5: Halıda Kullanılan Yıldız Motifleri (Keziban Selçuk, 2020)

G. 6: Halıda Kullanılan Yıldız Motifleri (Keziban Selçuk, 2020)

Bayburt merkezde bulunan ve 19. yüzyıla ait olan 200x400 cm ebatlarındaki yer yaygısı kilim, ilikli kilim dokuma tekniğiyle yapılmıştır (G. 7, G. 8). Dokumanın zemini diyagonal biçimde 11 bölüme ayrılmış olup etrafını geniş bir bordür çevrelemektedir. Zeminde ayrılan bu şeritlerin altıncısında sekiz kollu yıldız motifi yer almakta ve belli aralıklarla yedi kez tekrarlandı̆̆1 görülmektedir (G. 9).

22 Soysaldı, “Türklerde Yıldız Motifi ve Teke Yöresi Yıldızlı Zili (Burdur Müzesi) Örnekleri”, 426. 


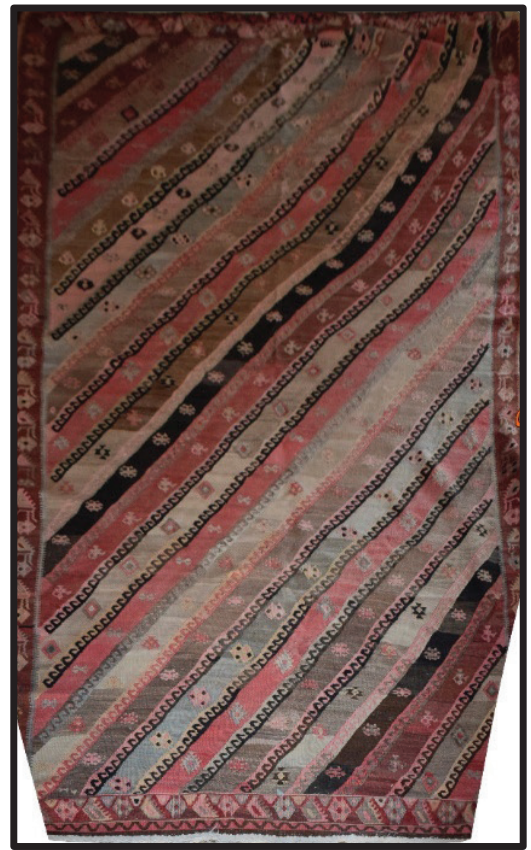

G. 7: Kilim Yer Yaygısı, 200x400 cm, 19. Yüzyıl (Bayburt Merkez) (Keziban Selçuk, 2019)

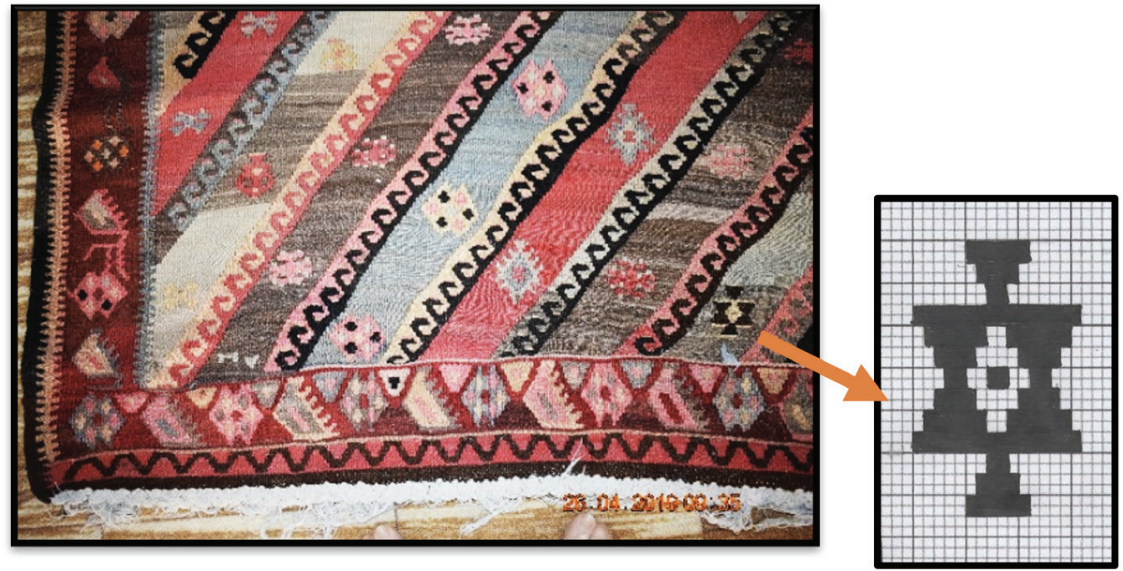

G. 8: Kilim Yer Yaygisı Detay

G. 9: Kilimde Kullanılan Yıldız Motifi (Keziban Selçuk, 2020)

\subsubsection{Altıgen, Sekizgen, Eşkenar Dörtgen, Kareden Oluşan Motifler}

Geleneksel Türk sanatlarında yüzey tezyinatında görülen altıgen, sekizgen, eşkenar dörtgen, kare şekiller sık sık ve genellikle yüzeylerde belli alanları oluşturmak maksadıyla uygulanan süsleme unsurları olarak kullanılmaktadır. Geometrik şekiller 
dokumalarda da sevilerek uygulanmakta, halı ve havsız kirkitli dokumalarda altıgen, sekizgen ve eşkenar dörtgenlerle meydana gelen ve Anadolu'da genellikle göbek/ göl olarak bilinen madalyonlarla karşımıza çıkmaktadır. Bazı dokumalarda Pazırık halısında olduğu gibi zemin karelere bölünerek oluşan alanlar içine motifler yerleştirilmektedir.

Doğu Karadeniz Bölgesi’nde üretilen dokumalarda da geometrik şekillerin yer aldığı alan araştırmalarında tespit edilmiştir. 19. yüzyılın ilk yarısında Şavşat'ın Hanlı Köyü'nde Gülperi Demirel tarafından 118x337 cm boyutlarında, ilikli kilim tekniğiyle dokunan yer yaygısı kilimin atkı ve çözgüsü yündür. Kilimde kullanılan renkler doğal boyalarla elde edilmiştir (G. 10, G. 11). Kilimin zemininde yöre insanının "göl" adını verdiği sekizgenler üst üste sıralanmakta sekizgenlerin dışında kalan bölümlerde ise yıldız, çarkıfelek, göz motifleri yer almaktadır (G. 12). Sekizgenlerin etrafında suyolu motifine yer verilmiştir. Sekizgen alanların içinde yörede "armut nakışı" olarak bilinen koçboynuzu ile kazayağı motifinden meydana gelen bir düzenleme yer almaktadır. Yer yaygısı kilim, Çayağzı Köyü’nde yaşayan Yaşar Yılmaz'ın evinde bulunmaktadır.

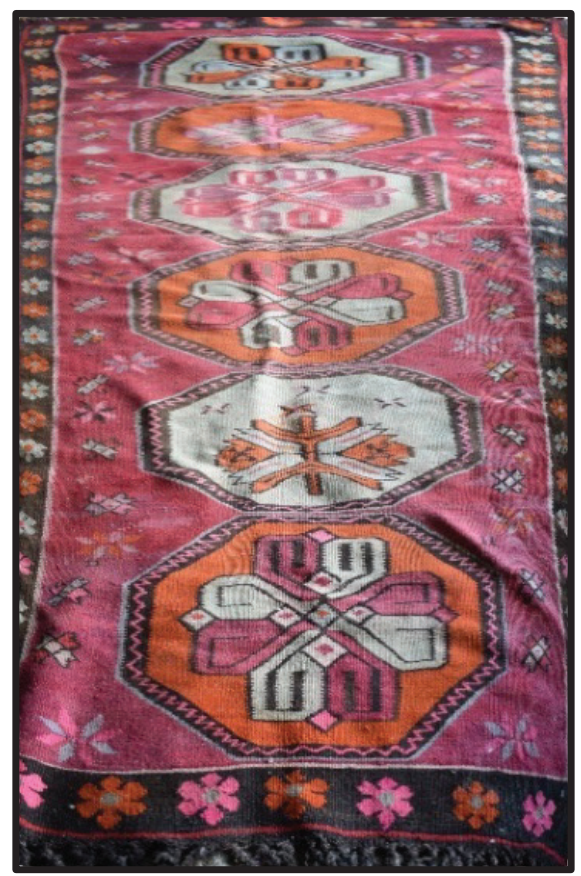

G. 10: Kilim Yer Yaygıs1, 118x337 cm. (Artvin İli- Şavşat İlçesi Çayağzı Köyü- Meryem Şenol’un Annesi Yaşar Yılmaz'ın Köy Evi) (Keziban Selçuk, 2019) 


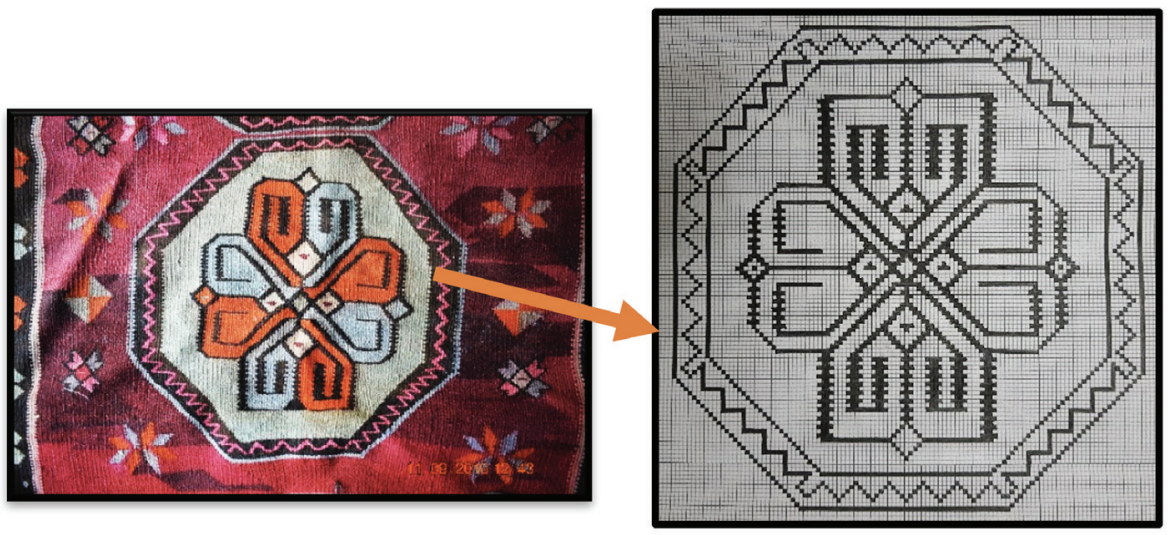

G. 11: Yer Yaygısında Kullanılan Sekiz Köşeli Madalyon

G. 12: Sekizgen Madalyon (Keziban Selçuk, 2020)

Bayburt merkeze bağlı Harmanözü Mahallesi'nde tespit edilen ve 20. yüzyıla ait olan 41x85 cm ebatlarındaki ilikli kilim tekniğiyle yapılan dokuma, yastık olarak kullanılmaktadır (G. 13, G. 14). Kilimin zeminini yan yana sıralanan ve uçlardan birbirine birleştirilerek dokunan eşkenar dörtgenler oluşturmaktadır (G. 15). Üç eşkenar dörtgenin etrafını ise çengel motifi çevrelemektedir. Eşkenar dörtgenlerin içine akrep motifi yerleştirilmiş, krem, açık yeşil, açık pembe ve turuncu renkler kullanılmıştır. Dokumanın geriye kalan zemin bölümlerinde ise eşkenar dörtgenin $1 / 2$ sinin tekrar edilmesiyle kompozisyon meydana getirilmiştir.

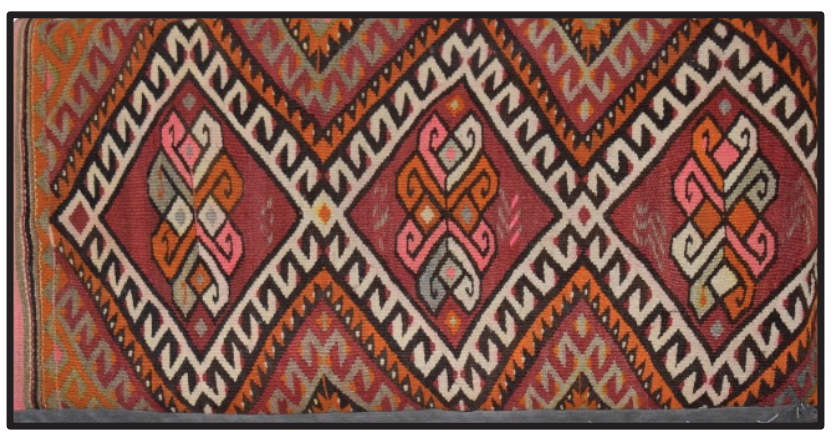

G. 13: Kilim Yastık, 41x85 cm, 20. Yüzyıl (Bayburt İli Harmanözü Mahallesi- Zümriye Aslan) (Keziban Selçuk, 2019) 

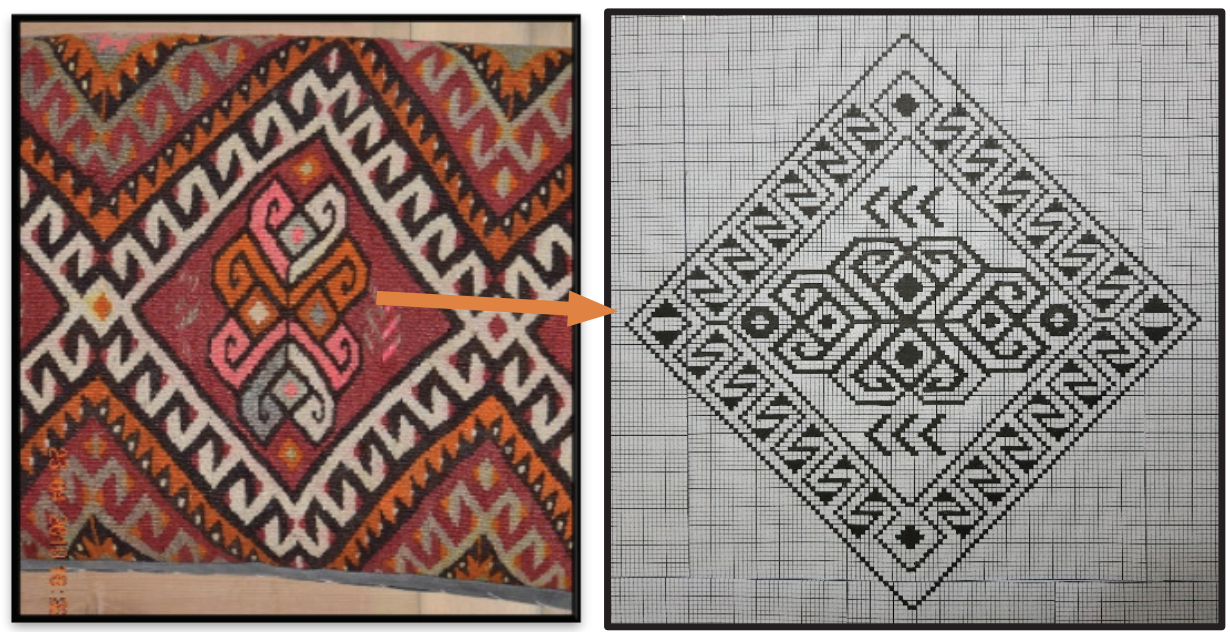

G. 14: Yastık Kullanılan Eşkenar Dörtgen

G. 15: Eşkenar Dörtgen Motifi (Keziban Selçuk, 2020)

\subsection{Bitkisel Motifler}

İnsanoğlu geçmişten bugüne kadar pek çok varlığı kutsal saymış ve bu varlıkları yazıya, dile, dine, sanata aktararak günümüze kadar ulaşmasını sağlamıştır. Doğanın sunduğu varlıklar içinde yer alan bitkiler de el sanatlarında natüralist veya stilize edilerek kullanılmıştır ${ }^{23}$.

Çiçek, dal yapraklardan meydana gelen motif grubunu teşkil eden bitkisel motifler, karanfil, lale, sümbül, papatya, gül, hatmi çiçeği, şakayık gibi çiçekler, natüralist biçimde kompozisyonlarda yer aldığı gibi, hatayi, gonca, penç, yaprak, hançer yaprak gibi stilize edilmiş biçimde de kullanılmıştır.

\subsection{1. Çiçek, Dal ve Yapraklar}

Bitkisel motifler, geleneksel Türk sanatlarının temel ögelerinden olup, çiçek, yaprak, dal, meyve ve ağaçlar bazen doğada var olan şekliyle yani natüralist biçimde bazen de aşırı derecede stilize edilerek tek başına veya diğer motiflerle birlikte kullanılmıştır ${ }^{24}$. Bölgede yapılan çalışma 2018 ve 2019 yıllarında yaz aylarında belli aralıklarla düzenlenen seyahatlerle gerçekleştirilmiştir. Doğu Karadeniz Bölgesi'nde gerçekleştirilen alan araştırmaları sonucunda Artvin, Bayburt, Giresun, Gümüşhane, Rize ve Trabzon' da yapılan dokumalarda genellikle çiçek, dal, yaprak, hayat ağacı ve pıtrak motiflerinin natüralist ve stilize edilerek kullanıldı̆̆ı tespit edilmiştir.

23 Gülşen Kahraman, "Türk Mitolojisinde Hayat Ağacı Motifi "Yaşam Ağacı” Konulu Seramik Pano Çalışması," XII. Uluslararası Türk Sanatı, Tarihi ve Folkloru Kongresi /Sanat Etkinlikleri, 25-27Nisan (April) 2019 (Konya: Selçuk Üniversitesi Türk El Sanatları Araştırma ve Uygulama Merkezi ve Konya Büyükşehir Belediyesi, 2019), 213.

24 Hülya Kaynar, “19. Yüzyıl Sonrası Dokunan Sivas Halısı Desenlerinde Bitkisel Motifler ve Özellikleri," Türk-İslam Medeniyeti Akademik Araştırmalar Dergisi, 13/26, (2018), 223. 
Artvin'in Şavşat ilçesine bağlı Kocabey Köyü’nde bulunan, 1957 yılında dokunan $55 \times 70 \mathrm{~cm}$ ebadındaki duvar halısında, Kelime-i Tevhit yazısının etrafinı simetrik olmayan biçimde çevreleyen çiçek, dal ve yapraklardan meydana gelen bir kompozisyon düzenlemesi vardır (G. 16).

Caminin minber kapısının üst bölümünde asılı olan halıda kullanılan bitkisel motifler natüralist biçimde ele alınmıştır (G. 17). Kocabey Köyü imamı Mehmet Enzin dokumayı yapan kişiyi bilmediklerini ifade etmiştir. Dokumanın atkı ve çözgüsü pamuk, ilmesi yündür.

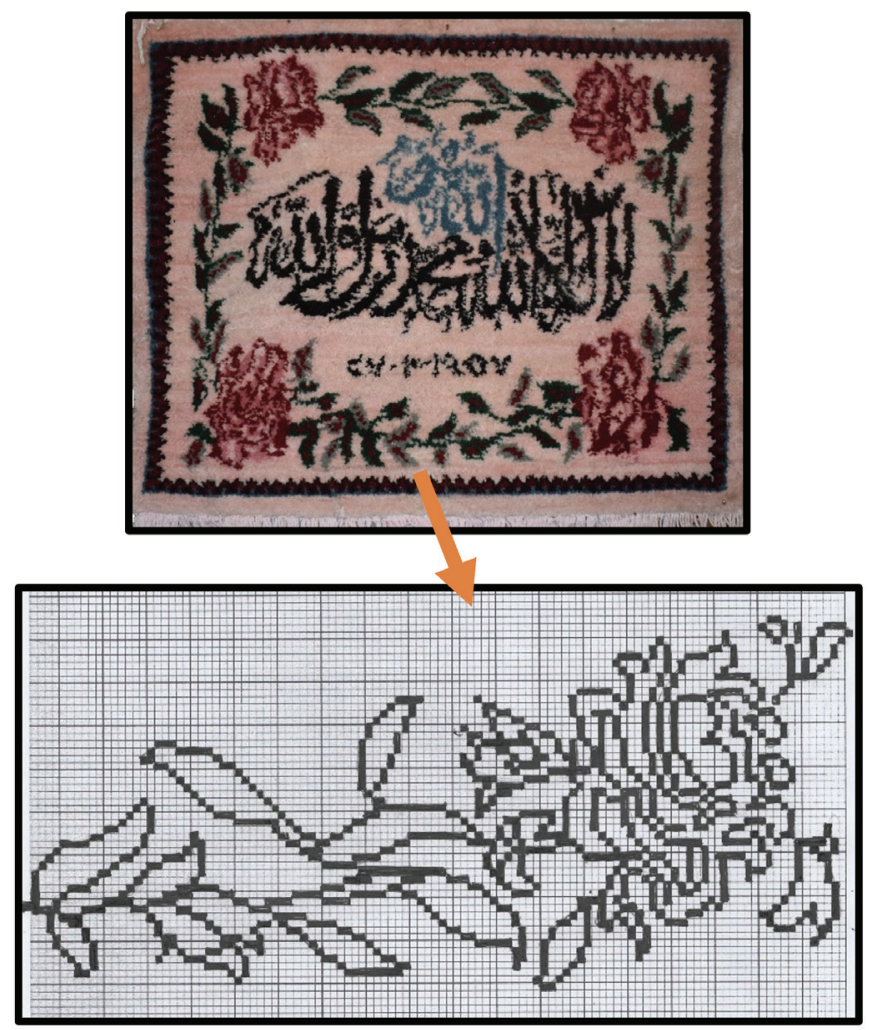

G. 16: Duvar Halıı1, 55x70 cm, 1957 (Artvin İli Şavşat İlçesi Kocabey Köyü Camii) (Keziban Selçuk, 2019)

G. 17: Sağ Alt Köşedeki Bitkisel Motiflerin (Çiçek, Dal ve Yapraklar) Çizimi (Keziban Selçuk, 2020)

Bitkisel motiflerin havsız kirkitli dokumalarda, özellikle Artvin ve Bayburt'ta bulunan dokumalarda sıkça kullanıldığg görülmektedir. Artvin'in Şavşat ilçesine bağlı Kocabey Köyü’nde bulunan, 1967 yılında 160x350 cm ebatlarında ilikli kilim tekniğiyle dokunan ve yörede "kedel sergisi" (duvar kilimi) olarak kullanılan kilim, Sofu Özdemir' in oturma odasında bulunan divanın (sedir) arkasındaki duvarın tamamını örtmektedir. Sofu Özdemir, kilimin dokunması sırasında motiflerin düzenlemesinin 
zor olması nedeniyle "yedi bela kilimi” olarak isimlendirildiğini ifade etmiştir (G. 18, G. 19). Siyah zemine sahip duvar kilimi, yedi sıradan meydana gelmektedir. Her sirada yer alan bir dal üzerinde natüralist biçimde çiçek ve yaprak motifleri bulunmaktadır (G. 20). Motifler bir üst sırada kaydırılmak suretiyle diyagonal olarak yerleştirilmiştir (G. 19).

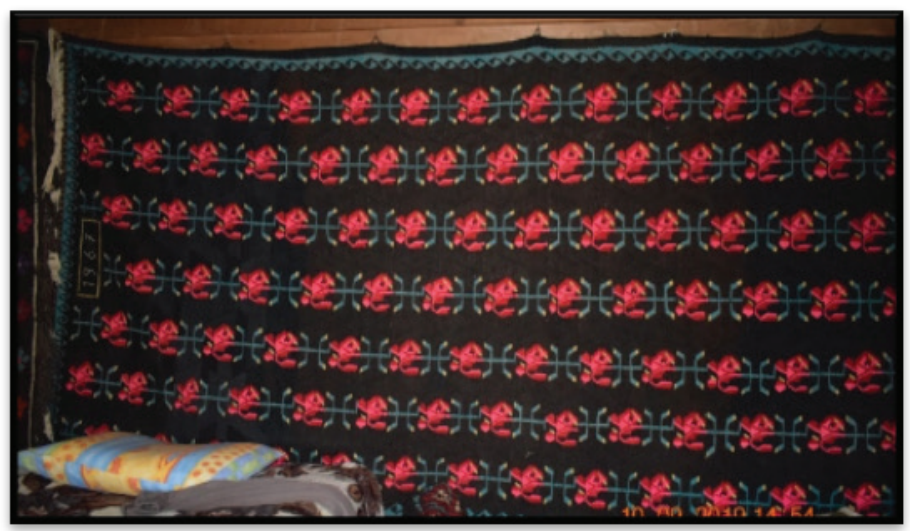

G. 18: Duvar Sergisi, 160x350 cm, 1967 (Artvin İli Şavşat İlçesi Kocabey Köyü-Sofu Özdemir'in Evi) (Keziban Selçuk, 2019)
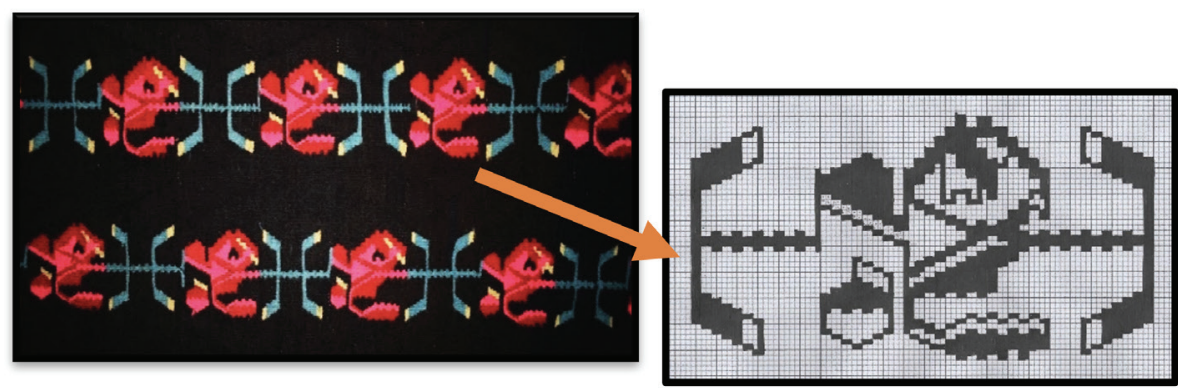

G. 19: Duvar Sergisinde Kullanılan Bitkisel Motifler

G. 20: Çiçek, Dal ve Yapraklardan Oluşan Bitkisel Motif Düzenlemesi (Keziban Selçuk, 2020)

G. 21'de yer alan kilim yer yaygısı, Artvin ili Şavşat ilçesi Kocabey Köyü'nde yaşayan Mahi Şeker Arslan'ın evinde bulunmaktadır. 20. yüzyılda dokunan 54x84 cm ebadındaki kilim yer yaygısının atkı ve çözgüsü yündür. Dokumanın hem zemini hem de bordürü yörede "yayla çiçeği” ve "kır çiçeği”" denilen çiçek motifiyle dolgulanmıştır (G. 23, G. 24). Zeminde stilize edilerek kullanılan çiçek motifinin renkleri diyagonal bir düzenlemeye uygun yerleştirilmiştir (G. 22). 


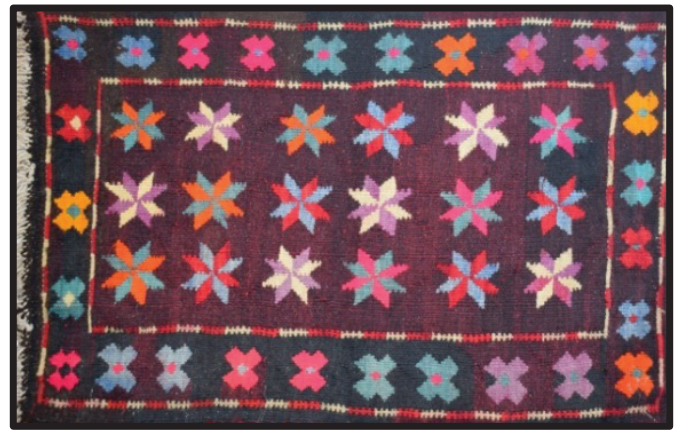

G. 21: Kilim Yer Yaygıs1, 54x84 cm, 20. Yüzy1l (Artvin İli Şavşat İlçesi Kocabey Köyü Mahi Şeker Aslan'ın Evi) (Keziban Selçuk, 2019)

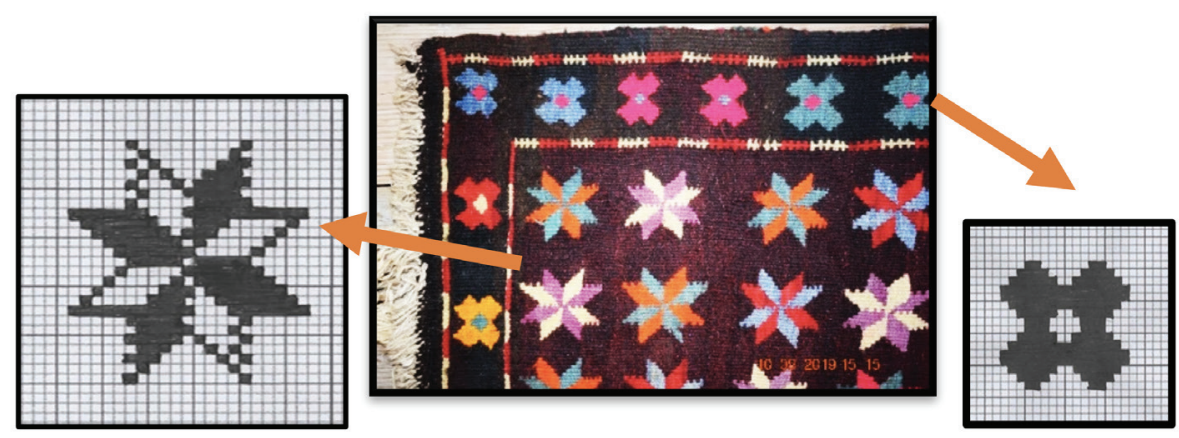

G. 22: Kilim Yer Yaygis1 Detay

G. 23: Yayla Çiçeği Motifi (Keziban Selçuk, 2020)

G. 24: Kır Çiçeği Motifi (Keziban Selçuk, 2020)

Bayburt merkeze bağl1 Harmanözü Mahallesi'nde Behçet Kaygusuz'un evinde bulunan ve 1989 yılında dokunan 120x234 cm ebadındaki kilim yer yaygısının kırmızı zemininde üst üste sıralanmış üç adet eşkenar dörtgen yer almaktadır (G. 25, G. 26). Çözgü ve atkısının yün olan kilimin zeminindeki ana motiflerin etrafı tarak motifi kullanılarak basamaklı biçimde düzenlenmiş, beyaz renkle dokunan bu alanlar içinde dal, yaprak ve çiçek motiflerine yer verilmiştir (G. 27). 


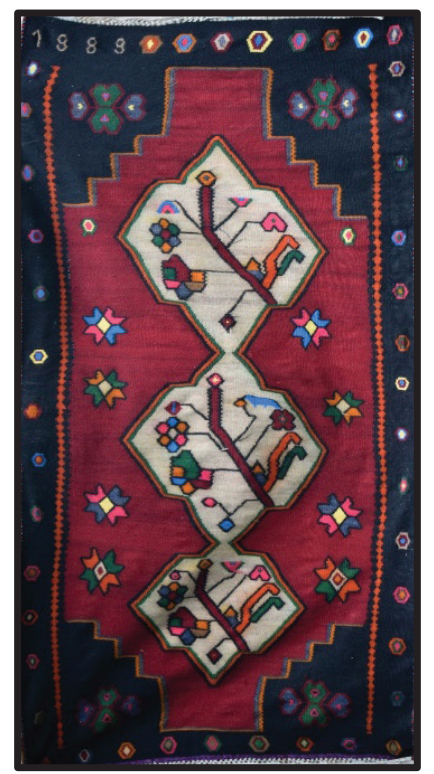

G. 25. Kilim Yer Yaygıs1, 120x234 cm, 1989 (Bayburt İli Harmanözü Mah. Behçet Kaygusuz’un Evi) (Keziban Selçuk, 2019)

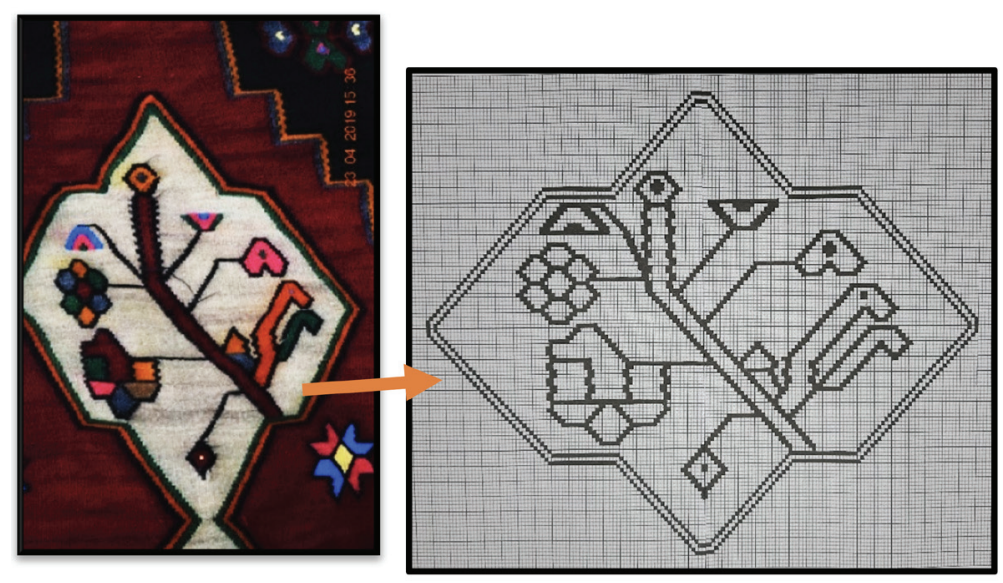

G. 26: Çiçek, Dal ve Yapraklardan Oluşan Bitkisel Motif Düzenlemesi (Keziban Selçuk, 2020)

G. 27: Çiçek, Dal ve Yapraklardan Oluşan Bitkisel Motifler (Keziban Selçuk, 2020)

Bayburt'un Demirözü ilçesi Beşpınar Beldesi'nde tespit edilen 19. yüzyılda dokunan 120x200 cm ebadındaki kilim namazlıkta, mihrabın ortasından aşağıya doğru sarkan kandil ve bunun iki tarafinda simetrik olarak düzenlenmiş çiçek motifleri yer almaktadır (G. 28, G. 29). Çiçek motifi, namazlığın hem mihrap içinde hem de mihrabın dışında yer alan köşelerinde görülmektedir. Namazlık Bayburt ve çevresine ait motif özellikleri taşımaktadır. Aynı motif, namazlıkta namaz kılan kişinin ayaklarını bastığı ve secdeye giderken ellerini koyduğu bölümlerde de kullanılmıştır (G. 30). 

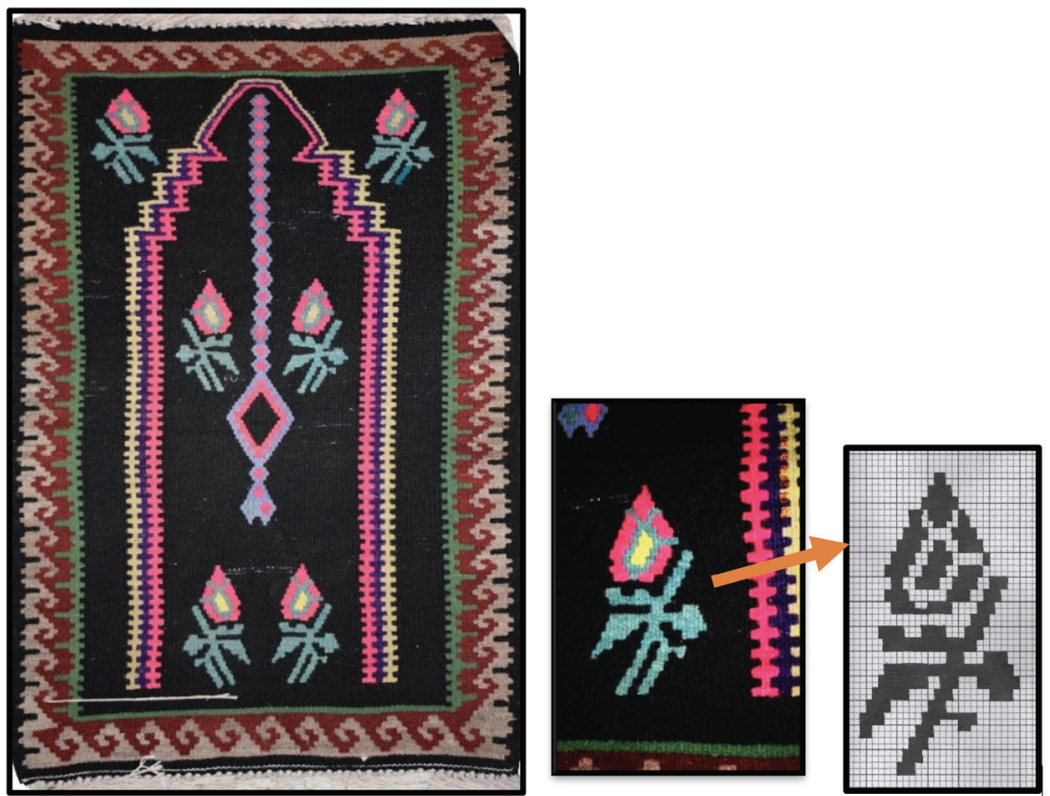

G. 28: Kilim Seccade, 120x200 cm, XIX. Yüzyıl (Bayburt İli-Demirözü İlçesi Beşpınar Beldesi Kenan Yavuz Kültür Evi) (Keziban Selçuk, 2019)

G. 29: Çiçek Motifi Detay

G. 30: Çiçek Motifi (Keziban Selçuk, 2020)

Bitkisel motiflerden çiçek, dal ve yaprak motiflerinin yer aldığı bölgede tespit edilen örneklerine bakıldığında, halı dokumalarda natüralist üslubun daha belirgin biçimde kullanıldığı gözlemlenmiştir. Buna rağmen havsız kirkitli dokumalarda ise dokuma tekniğine bağlı olarak motiflerin daha stilize biçimde ele alındığ 1 görülmektedir.

\subsubsection{Hayat Ağacı}

Bitkisel motiflerden biri olan hayat ağacı, sürekli değişim ve gelişim içinde yaşayan evreni sembolize etmektedir. Hayat ağacının en önemli özelliği, dünyanın merkezinde bulunması, yer altı, yer üstü ve gökyüzünü birbirine bağlamasıdır. Ağacın gövdesi büyük, gölgesi geniş ve yaprakları yaz kış canlıdır. Orta Asya ve Kuzey Asya mitolojisinde ağacın yedi ya da dokuz dalının bulunduğu ve yedi kat göğü temsil ettiği düşünülmektedir ${ }^{25}$.

Altaylılara göre, merkezde bulunan ve yeraltı, yerüstü ve gökyüzünü birleştiren çam ağacıdır ve dünyadaki ağaçların en büyüğüdür. Ağacın tepesinde de Bay Ülgen'in oturduğuna inanılmaktadır. Kökeni Orta Asya'ya dayanan hayat ağac1, Hunlar, Göktürkler, Uygurlar ve diğer Türk topluluklarının inançlarında yer almış, Şamanizm'de çok önemli bir sembol olmuştur ${ }^{26}$. Şaman kültüründe de ağaç kültü benimsenmiş ve

25 Pervin Ergun, Türk Kültüründe Ağaç Kültü (Ankara: Atatürk Kültür Merkezi Yayınları, 2017), 27.

26 Gülşen Kahraman, “Türk Mitolojisinde Hayat Ağacı Motifi "Yaşam Ağacı”, 214. 
Şaman ağacı olarak gelişme göstermiş, şaman davulu üzerine de dünya ağacı tasvirleri çizilmiştir. Ağaç Yakutlarda da kullanılan ana ağaca benzemektedir ${ }^{27}$. Özellikle yaşlı ve geniş gövdeli ve yüksek tepeli ağaçların yanından geçen insanlar, ağaçların önünde diz çökerek saygı göstermişlerdir. Günümüzde de Anadolu'nun pek çok yerinde "kutsal ağaç kültü” devam etmektedir ${ }^{28}$.

Hayat ağacı Osmanlı'da aynı zamanda güç ve iktidarın sembolüdür29. Motif, "Devletlû kaba ağaç" deyimiyle sembolize edilmiş, Osman Gazi’nin rüyasında gördüğü kendi göbeğinden çıkan bir ağacın tüm dünyayı sarması, Osman Bey’in devletinin, dünya hâkimiyeti kuracağına yorumlanmıştır ${ }^{30}$.

Geçmişten günümüze geleneksel Türk sanatlarında kullanılan hayat ağacı motifi Doğu Karadeniz Bölgesi dokumalarında da görülmektedir. Bulunan dokuma örneklerinde genellikle vazo içinden çıkan çiçek demetine rastlanmakta ve bölgede görüşülen kaynak kişiler tarafından "hayat ağacı" motifi olarak adlandırılmaktadır.

Artvin'de bulunan kilim dokumada da motifin kullanıldığı görülmektedir. Çalışma kapsamında Artvin'in Şavşat ilçesine bağlı Kocabey Köyü’nde bulunan ve üzerinde 24.2.1960 tarihi bulunan 143×363 cm ebadındaki duvar (kedel) sergisinin zemininde sıralanan çiçek demetlerine bu köyde yaşamını sürdüren ve dokumacılığı bilen 66 yaşındaki Nebiye Aslan tarafından "hayat ağaçlı kilim” denilmiştir (G. 31). Kırmızı zemini bulunan kilimde üç sıra halinde turuncu, mavi ve turuncu renkteki on adet vazodan çıkan çiçek demetleri dokunmuştur (G. 32). Dokumada içinde stilize çiçeklerin yer aldığı koçboynuzu motifinden meydana gelen bir bordür bulunmaktadır.

27 Fuzuli Bayat, Türk Mitolojik Sistemi (Kutsal Dişi. Mitolojik Ana, Umay Paradigmasinda İlkel Mitolojik Kategoriler. İyeler ve Demonoloji) 2, (İstanbul: Ötüken Neşriyat A.Ş., 2012), 188.

28 Nursel Balcı, "Türk Halı Sanatında Mitolojik Kaynaklı Bazı Motifler," Arış 8 (Kasım 2012), 44.

29 Nursel Balcı, "Türk Halı Sanatında Mitolojik Kaynaklı Bazı Motifler," 44.

30 H. Feriha Akpınarlı ve H. Ayşegül Özdemir, "Konya-Lâdik Halılarındaki Motiflerin İncelenmesi”, İdil Sanat ve Dil Dergisi 5/23 (2016), 977. 


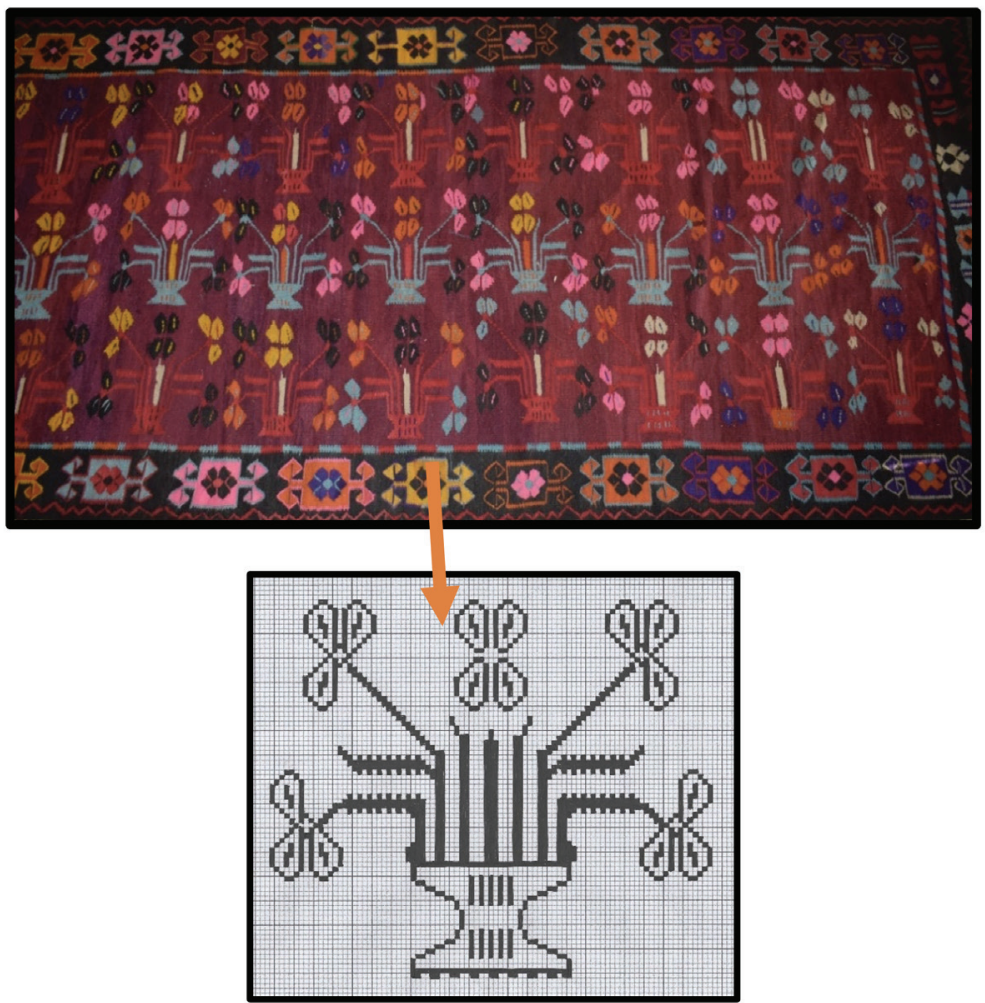

G. 31: Duvar Sergisi, 143x363cm, 24.2.1960 (Artvin İli Şavşat İlçesi Kocabey Köyü Camii) (Keziban Selçuk, 2019)

G. 32: Hayat Ağacı Motifi (Keziban Selçuk, 2020)

\subsubsection{Pitrak Motifi}

Pltrak, tarlalarda bulunan dikenli bir bitki olup, dikenleriyle insana ve hayvanlara yapışır. Anadolu'da kullanılan pıtrak motifi, bu bitkinin stilize edilmiş biçimidir. Pıtrak motifi, Çatalhöyük'te bulunarak Ankara Anadolu Medeniyetleri Müzesinde sergilenen ve M.Ö. 5850 yılına tarihlendirilen neolitik dönemden kalan, pişmiş topraktan yapılmış bir mührün üzerinde de görülmektedir. Bu motif, seramik, metal, dokuma ve benzeri el sanatlarında da kullanılmaktadır ${ }^{31}$. Pıtrağın üzerindeki dikenlerin, kötü gözü uzaklaştırdığına inanıldığı için, Anadolu insanı tarafından nazarlık motifi olarak kullanılmıştır. "Pıtrak gibi" deyimiyle ağaçlardaki çiçek ve meyvenin bolluğundan bahsedilmektedir. Bu nedenle, pıtrak motifi, bolluk ve bereketi simgelemekte olup un çuvallarında, tandır örtülerinde, ekmek üzerine örtülen cicimlerde sıkça kullanılmıştır ${ }^{32}$.

31 Ahmet Diler ve Marc Antoine Gallice, Kilimin Sembolleri (İstanbul: Alfa Basım Yayım Dă̆ııım San ve Tic. Ltd. Şti.,2018), 100.

32 Erbek, Çatalhöyük'ten Günümüze Anadolu Motifleri, 108; Serkan İlden ve Adalat Anvarova, "Ukrayna ve Türk Sanatlarında Görülen Benzer Sembol ve Motifler," XII. Uluslararası Türk Sanatı, Tarihi ve Folkloru Kongresi Sanat Etkinlikleri, 25-27 Nisan (April) 2019, (Konya: Selçuk Üniversitesi Türk El Sanatları Araştırma ve Uygulama Merkezi ve Konya Büyükşehir Belediyesi, 2019), 670. 
Doğu Karadeniz Bölgesi’nde Bayburt, Giresun ve Gümüşhane merkez ve ilçelerinde yapılan havsız kirkitli dokumalarında görülen pıtrak motifi, genellikle yayg1ların zemininde kullanılan ana motiflerden biridir. Özellikle Giresun’un Alucra ilçesinde “ala kilim”, Gümüşhane’nin Kelkit ile Şiran ilçesi ve köylerinde yapılan “zilli kilimi” adı verilen yer yaygısında pıtrak motifine sık rastlanmaktadır. Günümüzde tek parça ve büyük boyutlarda dokunan zilli kilimi yer yaygısı olarak kullanılmakta, heybe, yastık, yolluk, duvar süsleri, nazarlık, isimlik, seccade olarak da üretilmektedir. Çuvallara dokunan zilli kilim motifleri günümüzde sanat değeri taşımaktadır. Kelkit'te yapılan bu dokumalarda genellikle koyu renkler görülmektedir ${ }^{33}$. Dokumalar el eğirmesi iplikle ve tek taraflı olarak yapılmakta, motifler yüzeyde kabarık bir görünüm sergilemektedir. Giresun'un Alucra ilçesi Akçiçek (Davaha) Mahallesi'nde yaşayan Kiymet Doruk ile Fidan Doruk, Gümüşhane'nin Kelkit ilçesinden İbrahim Çelebi, Kızılca Mahallesi'nden Hatice Dinç, Reşadiye Dinç ve Şiran ilçesinden Neşe Demir Halep, pıtrağın koyunların yününe yapışan dikenli bitki olduğunu ifade etmekte ve motifi yörede "per” olarak adlandırmaktadırlar. Görüşme yapılan kaynak kişiler büyüklerinden edindikleri bilgiler 1şı̆̆ında dokuma geleneğini günümüzde devam ettirmekte, motifin büyük, küçük ve karmaşık oluşuna göre "büyük per”, "küçük per”, “aynalı per”, "çerçeveli şeytan perli”, "şeytan perlinin yarımı” gibi isimler kullanmaktadırlar.

Doğu Karadeniz Bölgesi'nde yapılan alan araştırmasında bulunan dokumalarda pıtrak motifine sıkça yer verildiği gözlemlenmiştir. Dokumalardan biri, Bayburt merkezde tespit edilen 19. yüzyıla ait 200x400 cm ebadındaki kilim yer yaygısıdır (G. 33, G. 34). Koyu kahverengi olan yaygının zemininde 56 adet pitrak motifi sıralanmıştır (G. 35).

33 Aynur Yüce ve Hülya Demir Yaleze, “Türkiye'de Cittaslow (Yavaş Şehir) Hareketi ve Bir Öneri: Gümüşhane Merkez İlçesi," The Journal of International Scientific Researches, Uluslararası Bilimsel Araștırmalar Dergisi, Markaya Dair Her Şey Bu Kongrede (Kongre Özel Sayısl) 3/4 (Gümüşhane: Gümüşhane Üniversitesi İktisadi ve İdari Bilimler Fakültesi, 2018), 167. 

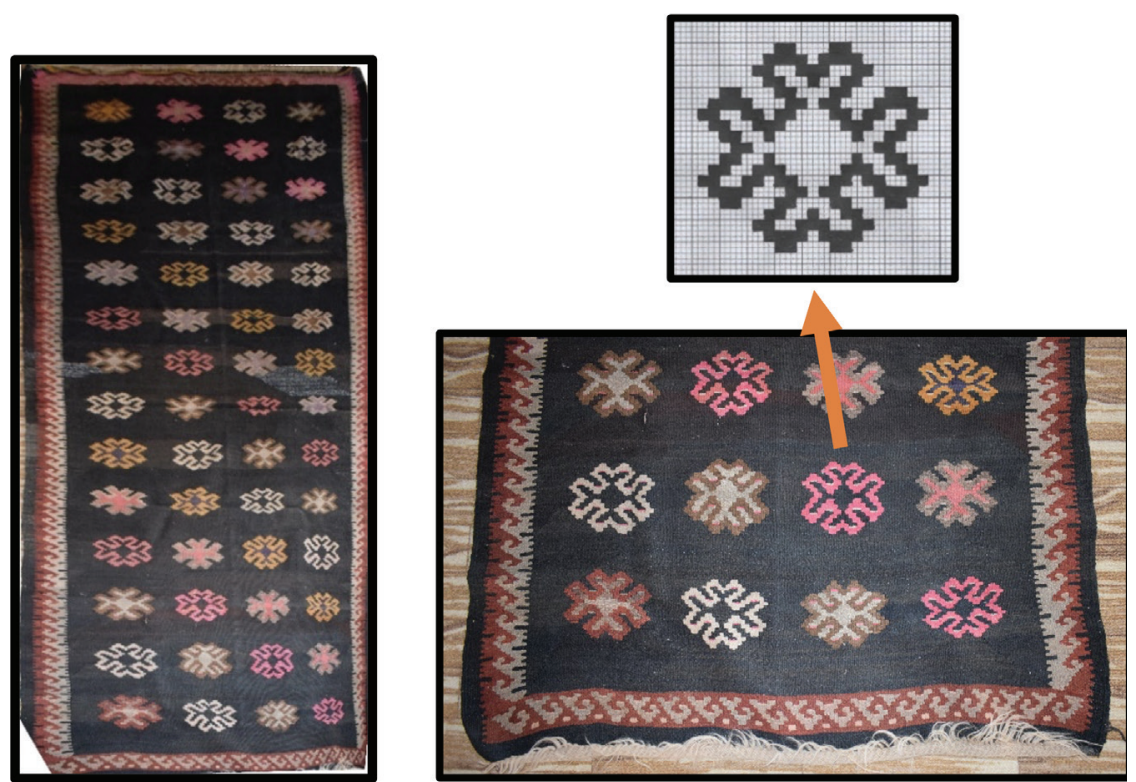

G. 33: Kilim Yer Yaygısı, 200x400 cm, 19. Yüzyıl (Bayburt İli-merkez) (Keziban Selçuk, 2019) G. 34: Yer Yaygisı Detay

G. 35: Pitrak Motifi (Keziban Selçuk, 2020)

Giresun'da bulunan 20. yüzyıla ait $215 \times 310 \mathrm{~cm}$ ebadındaki palaz kilimi veya Davaha kilimi adı verilen yer yaygısında zili tekniği kullanılmıştır (G. 36). Kıymet Doruk tarafından dokunan ve Giresun'un Alucra ilçesine bağlı Akçiçek (Davaha) Köyü'nde bulunan yer yaygısının "per" adı verilen pıtrak motifinin yan yana s1ralanmasıyla oluştuğu Kıymet Doruk ve Fidan Doruk tarafından ifade edilmiştir. Yer yaygisının zemini gruplar hâlinde yatay bantlardan meydana gelmekte ve grup isimleri zeminlerinde kullanılan renge göre "ala", "ağ ala" ve "sarı ala" olarak isimlendirilmektedir. Motif, G. 37'de olduğu gibi "ala" grubunda iki sıra hâlinde tekrarlanmaktadır (G. 38). 

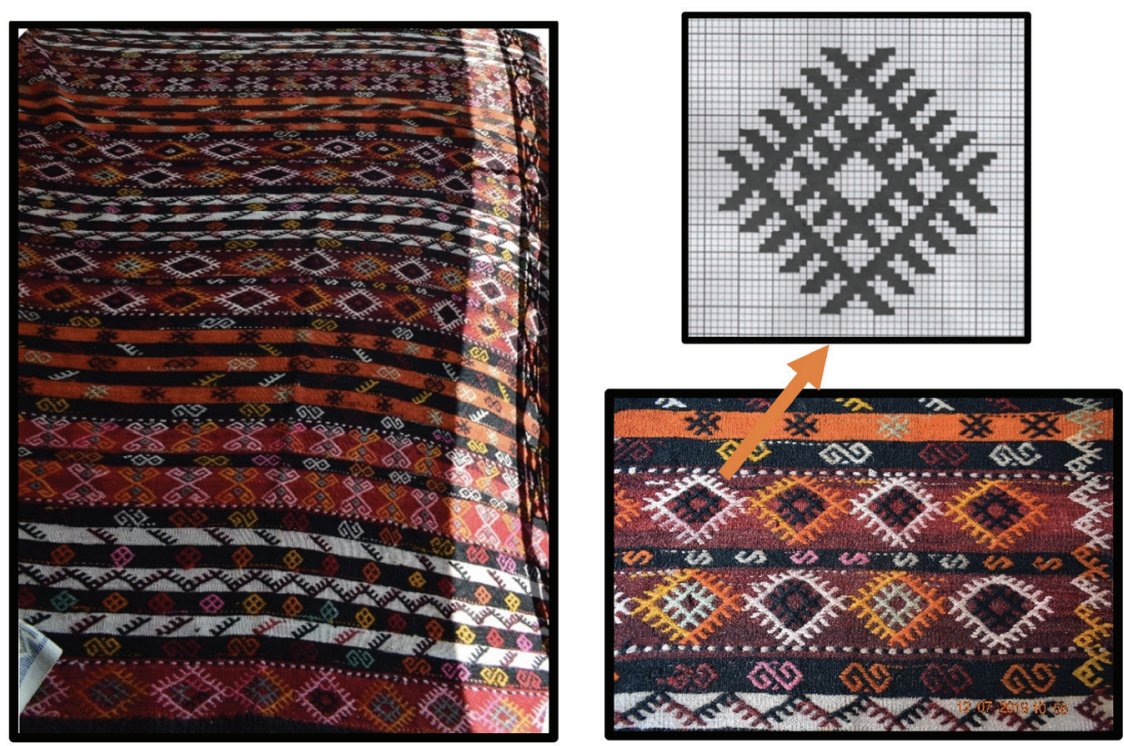

G. 36: Palaz Kilimi (Yer Yaygıs1), 215x310 cm, 20. Yüzy1l (Giresun İli Alucra İlçesi Akçiçek (Davaha) Köyü-Kıymet Doruk'un Evi) (Keziban Selçuk, 2019)

G. 37: Palaz Kilimi Detay

G. 38: P1trak Motifi (Keziban Selçuk, 2020)

Gümüşhane'nin Kelkit ilçesine bağlı Kızılca Köyü’nde tespit edilen 19. yüzyıla ait 120x350 cm ebadındaki yer yaygısı Ürkiye Hanım'ın evinde bulunmuştur (G. 39, G. 40). Zilli kiliminde kullanılan ve yörede "çerçeveli şeytan perli" ile "şeytan perlinin yarımı" olarak ifade edilen motif, pıtrak motifidir (G .41). Gümüşhane ve Giresun'da genellikle havsız kirkitli dokumalarda zili dokuma tekniği kullanılmakta, pıtrak motifinin de tekniğe uygun olması bakımından tercih edildiği düşünülmektedir. 

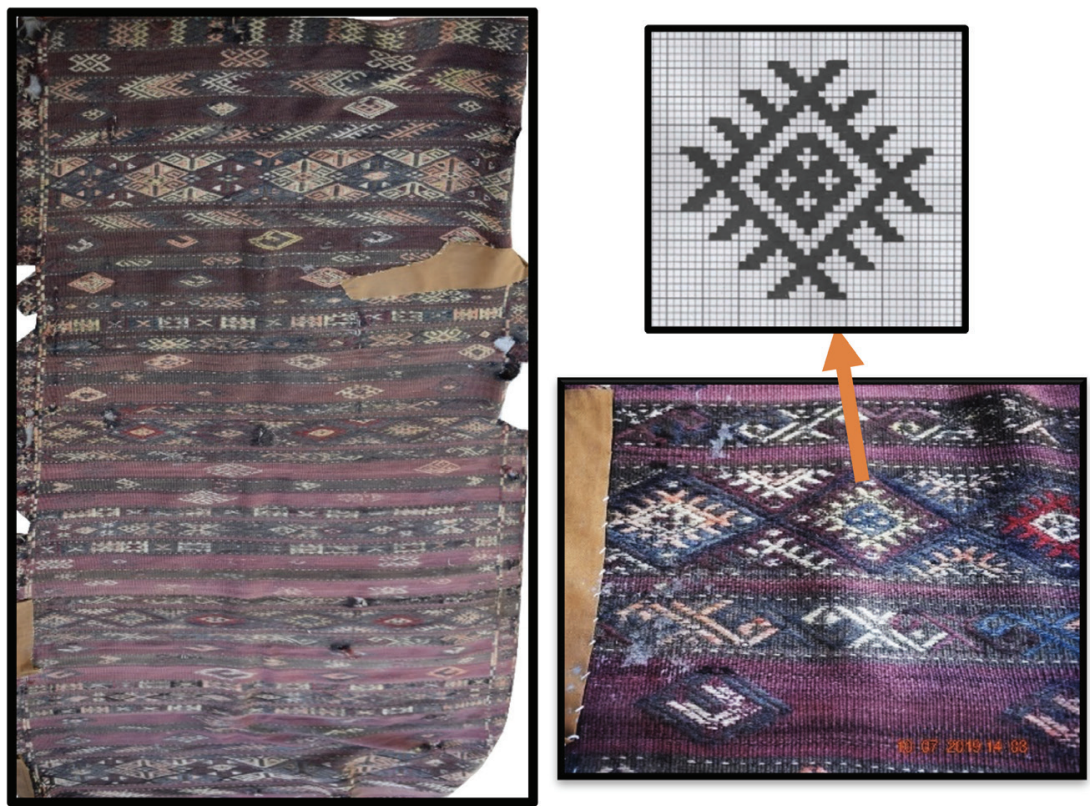

G. 39: Zilli Kilim (Yer Yaygısı), 120x350 cm, 19. Yüzyıl (Gümüşhane İli- Kelkit İlçesi Kızılca Köyü-Ürkiye Hanım'ın Evi) (Keziban Selçuk, 2019)

G. 40: Zilli Kilimden Detay

G. 41: P1trak Motifi (Keziban Selçuk, 2020)

\section{Sonuç}

Anadolu havlı ve havsız kirkitli dokumalar üzerinde yer alan motifler oldukça zengindir. Anadolu'nun bütün bölgelerinde olduğu gibi Doğu Karadeniz Bölgesi'nde yapılan dokumalar üzerinde kullanılan motifler çeşitli şekillerde gruplandırılmaktadır. Bunlardan birini geometrik diğerini de bitkisel motifler oluşturmaktadır. Yıldız, altıgen, sekizgen, üçgen, eşkenar dörtgen, kare ve dikdörtgenlerin oluşturduğu geometrik motifler, bütün sanat dallarında kullanılmaktadır. İlk geometrik motif örnekleri ise Pazırık halısının kare alanlara bölünmesinden meydana gelen zemininde görülmektedir. Doğu Karadeniz Bölgesi'nde yapılan araştırma sonucu ele alınan örneklerde geometrik motiflerin yer aldığı, Artvin ve Bayburt'ta tespit edilen dokumaların motif açısından oldukça zengin olduğu gözlemlenmiştir. Bayburt merkezdeki kilim yer yaygısı ile Demirözü İlçesine bağlı Beşpınar Beldesi'nde bulunan halı dokumada sekiz kollu yıldız motifi yer almaktadır. Artvin'in Şavşat ilçesine bağlı Çayağzı Köyü’ndeki kilim yer yaygısının zemininde yöre insanı tarafından "göl" adı verilen sekizgenler yer alırken, Bayburt'un Harmanözü Mahallesi'ndeki kilim dokuma yastıkta ise eşkenar dörtgenler yan yana sıralanmıştır. Yıldız, eşkenar dörtgen, kare, sekizgen ve altıgenlerin yer aldı$\breve{g} 1$ geometrik motiflerin, bölgede tespit edilen dokumaların zemininde genellikle ana motif olarak uygulandığı verilen örneklerden anlaşılmaktadır. Yıldız motifi özellikle Artvin'in il, ilçe ve köylerinde genellikle çiçek motifi olarak bilinmektedir. 
Doğu Karadeniz Bölgesi'nde gerçekleştirilen alan araştırması sonucunda bölgedeki dokumalarda bitkisel motif olarak genellikle stilize çiçek, dal, yaprak, hayat ağacı ve pıtrak motiflerinin kullanıldığ1 görülmektedir. Artvin’in Şavşat İlçesine bağl1 Kocabey Köyü'nde bulunan caminin minber kapısının üstünde asılı duran duvar halısının zeminindeki Kelime-i Tevhid yazısının kenarlarını çiçek, dal ve yapraklardan meydana gelen natüralist bitki motifleri süslemektedir. Yine Şavşat’ta bulunan iki ayrı yer yaygısında da stilize çiçek motifleri kullanılmıştır. Bayburt ili Demirözü ilçesine bağlı Beşpınar Beldesi’nde bulunan kilim namazlığın mihrap içi ve köşelerindeki çiçek motifi ile Artvin ili Şavşat ilçesi Kocabey Köyü'nde bulunan yer yaygısının hem zemin hem de bordüründe yer alan "yayla çiçeği” ve "kır çiçeği”" olarak bilinen çiçek motifleri bölgedeki en güzel örnekleri teşkil etmektedir. Bu dokumalarda yöresel isim farklılıkları olmasına rağmen yer alan motifler Türk kültürünün birikimi ve sentezinin sonucunda ortaya çıkan motiflerdir. Artvin'in Şavşat ilçesine bağlı Kocabey Köyü’nde tespit edilen duvar sergisi üzerinde yer alan vazodan çıkan çiçek demetlerinden dolayı "hayat ağaçlı kilim" olarak isimlendirilen ve bitkisel motiflerden olan hayat ağacı, yeralt1, yeryüzü ve gökyüzünün bir sembolü olarak dokumalarda geçmişten günümüze kullanılmaktadır. Bölgede özellikle havsız kirkitli dokumalarda yer alan, bolluk ve bereketi temsil eden pitrak ise özellikle Giresun'un Alucra ilçesi ve köyleriyle, Gümüşhane'nin Kelkit ile Şiran ilçesi ve köylerinde yapılan zililerde kullanılan tekniğe uygun olmasından dolayı sık görülen motiflerden biridir.

Günümüzde dokumac1lık eskiye nazaran daha az yapılmasına rağmen bugün yap1lan örneklerde de geleneksel motiflerin anlamlarının bilinerek veya bilinmeyerek aynı biçimde devam ettirildiği görülmektedir. Bölgede il ve ilçelerde bulunan halk eğitim merkezleri, belediyeler, valilik, kaymakamlık bünyesinde yapılan projeler ve açılan kurslarla birlikte bazı kişisel çabaların olması da dokumacılığın geleneksel biçimde devam etmesinde etkilidir.

Hakem Değerlendirmesi: Dış bağımsız.

Çıkar Çatışması: Yazarlar çıkar çatışması bildirmemiştir.

Finansal Destek: Yazarlar bu çalışma için finansal destek almadığını beyan etmiştir.

Peer-review: Externally peer-reviewed.

Conflict of Interest: The authors have no conflict of interest to declare.

Grant Support: The authors declared that this study has received no financial support.

\section{Kaynakça/References}

Akar, Ali ve Mustafa Karataş. "Milas Halı ve Kilimleri İçin Kullanılan Yanış (Motif) Adlarının Dil İncelemesi.” Arış 5 (Mart 2011): 6-11.

Akpınarl1, H. Feriha ve H. Ayşegül Özdemir. "Konya-Lâdik Halılarındaki Motiflerin İncelenmesi." İdil Sanat ve Dil Dergisi 5/23 (2016): 955-982.

Aslanapa, Oktay. Türk Halı Sanatının Bin Yllı. İstanbul: İnk1lap Kitabevi, 2005. 
Balcı, Nursel. "Türk Halı Sanatında Mitolojik Kaynaklı Bazı Motifler.” Arış 8 (Kasım 2012): 38-51. Bayat, Fuzuli. Türk Mitolojik Sistemi (Kutsal Dişi. Mitolojik Ana, Umay Paradigmasında İlkel Mitolojik Kategoriler. Iyeler ve Demonoloji) 2. İstanbul: Ötüken Neşriyat A.Ş., 2012.

Çiloğlu, Hakan. "Türk Halı Sanatı Kompozisyonlarında Hayat ve Zaman Kavramları.” Atatürk Üniversitesi Güzel Sanatlar Enstitüsü Dergisi 43 (2019): 200-213.

Deniz, Bekir. "Anadolu-Türk Halı ve Düz Dokuma Yaygılarında Bazı Motiflerin İsimlendirilmesi.” Akdeniz Sanat Dergisi 3/5 (2010): 51-74.

Diler, Ahmet ve Marc Antoine Gallice. Kilimin Sembolleri. İstanbul: Alfa Basım Yayım Dağıtım San ve Tic. Ltd. Şti., 2018.

Erbek, Mine. Çatalhöyük'ten Günümüze Anadolu Motifleri. Ankara: T.C. Kültür Bakanlığı, 2002.

Ergün, Gürkan. "Weaving in Anatolia in Prehistoric Period". IV. International Multidisciplinary Congress of Eurasia (27-30 Nisan 2017) / Barcelona/İspanya, 2017), 118-128. Erişim 10 Ağustos 2019.

https://www.imcofe.org/2017/barcelona/Download/imcofebarcelonafulltext2017.pdf.

Ergun, Pervin. Türk Kültüründe Ağaç Kültü. Ankara: Atatürk Kültür Merkezi Yayınları, 2017.

Gülay, Abdullah. Ăgasar Çepni Kültürü Geyikli Folklor- İnceleme-Araştırma. İstanbul: Geyikli Belediyesi Kültür Yayınları-1, 2001.

Kahraman, Gülşen. "Türk Mitolojisinde Hayat Ağacı Motifi "Yaşam Ağacı” Konulu Seramik Pano Çalışması." XII. Uluslararası Türk Sanatı, Tarihi ve Folkloru Kongresi /Sanat Etkinlikleri, 25-27Nisan (April) 2019. Konya: Selçuk Üniversitesi Türk El Sanatları Araştırma ve Uygulama Merkezi ve Konya Büyükşehir Belediyesi, 2019, 213-217.

Karamağaralı, Beyhan. “Türk Halı Sanatındaki Motiflerin Yorumu Üzerine.” Arış 3 (1997): 28-39.

Kaynar, Hülya. "19. Yüzy1l Sonrası Dokunan Sivas Halısı Desenlerinde Bitkisel Motifler ve Özellikleri.” Türk-İslam Medeniyeti Akademik Araştırmalar Dergisi 13/26 (2018): 221-244.

Kuruca, Nazım ve Muammer Ak. "Doğu Karadeniz Bölgesinde Konargöçer Hayata Dair Uygulamalar: Giresun Örneği." UKDA (A. Haluk Dursun Anısina Uluslararası Türk Kültürü Sempozyumu Dil-Tarih-Coğrafya 6-8 Aralık 2019) 788-793. Erişim 20 Aralık 2020. http://giramer.giresun.edu. tr/Files/ckFiles/giramer-giresun-edu-tr/Makaleler/Muammer\%20AK.pdf.

Özkan, Haldun. Sanat Tarihine Giriş Ders Notları. Erzurum: Zafer Medya, 2017.

Pala, İskender. "Mühr-i Süleyman", TDV İslam Ansiklopedisi. 31. İstanbul: Türkiye Diyanet Vakfı Yayınlar1, 2006, 524-526.

Rize El Sanatları. Rize: Rize Halk Eğitim Merkez Müdürlüğü Yayınları, 2004.

Selçuk, Keziban. “Doğu Karadeniz Bölgesi Dokumaları.” Doktora tezi, Atatürk Üniversitesi, 2020.

Soysald1, Aysen. "Türklerde Yıldız Motifi ve Teke Yöresi Yıldızlı Zili (Burdur Müzesi) Örnekleri.” Maddi Kültür, 9. Milletlerarası Türk Halk Kültürü Kongresi (Ankara: T.C. Kültür ve Turizm Bakanlığı Araştırma ve Eğitim Genel Müdürlüğü, 2017), 425-439.

Sümerkan, Mustafa Reşat. Trabzon Yöresi Geleneksel El Sanatları. Trabzon: Serander Yayınları, 2008 .

Uğurlu, Aydın. “Anadolu Dokumalarında Motif Felsefesi.” Tekstil ve Mühendis 5 /26 (Nisan 1991): 76-82. Erişim 10 Kasım 2020. https://dergipark.org.tr/tr/pub/teksmuh/issue/12908/156221.

Uğurlu, Aydın ve Servet Senem Uğurlu, “Anadolu Kirkitli Halk Dokumalarında Felsefi Yorumlara Açık Bazı Motifler.” II. Uluslararası Felsefe, Eğitim, Sanat ve Bilim Tarihi Sempozyumu, (03-07 May1s), (Muğla: Muğla Sitkı Kocaman Üniversitesi Atatürk Kültür Merkezi, 2017), 1467-1475. 
Yağan, Şahin Yüksel. Türk El Dokumacılı̆̆ı. İstanbul: Türkiye İş Bankası Kültür Yayınları, 1978. Yüce, Aynur ve Hülya Demir Yaleze. "Türkiye'de Cittaslow (Yavaş Şehir) Hareketi ve Bir Öneri: Gümüşhane Merkez İlçesi”, The Journal of International Scientific Researches, Uluslararası Bilimsel Araştırmalar Dergisi, Markaya Dair Her Şey Bu Kongrede (Kongre Özel Sayısı) 3/4 (Gümüşhane: Gümüşhane Üniversitesi İktisadi ve İdari Bilimler Fakültesi, 2018): 158-180.

Erişim 18 Aralık 2019. https://www.tekstilbilgi.net/dunyanin-en-eski-kumaslari.html.

\section{Kaynak Kişiler}

Behçet Kaygusuz (55), Bayburt İli Harmanözü Köyü (23.04. 2019).

Zümriye Aslan, Bayburt İli Harmanözü Köyü (23.04. 2019).

Kenan Yavuz (?), Bayburt İli Demirözü İlçesi Beşpınar Beldesi Kenan Yavuz Kültür Evi Kurucusu (24.04.2019).

Ürkiye Hanım (?), Gümüşhane İli Kelkit İlçesi Kızılca Mahallesi (10.07.2019).

Hatice Dinç (85), Gümüşhane İli Kelkit İlçesi Kızılca Mahallesi (10.07.2019).

Reşadiye Dinç (63), Gümüşhane İli Kelkit İlçesi Kızılca Mahallesi (10.07.2019).

Neşe Demir Halep (47), Gümüşhane İli Şiran İlçesi Halk Eğitim Merkezi Usta Öğretici (11.07.2019).

Fidan Doruk (60), Giresun İli Alucra İlçesi (12.07.2019).

Kıymet Doruk (75), Giresun İli Alucra İlçesi Akçiçek (Davaha) Mahallesi (12.07.2019).

Sofu Özdemir (71), Artvin İli Şavşat İlçesi Kocabey Köyü (10.09.2019).

Mahi Şeker Aslan (68), Artvin İli Şavşat İlçesi Kocabey Köyü (10.09.2019).

Nebiye Aslan (66), Artvin İli Şavşat İlçesi Kocabey Köyü (10.09.2019).

Mehmet Enzin (43), Artvin İli Şavşat İlçesi Kocabey Köyü Camii İmamı (10.09.2019).

Meryem Şenol (42), Artvin İli Şavşat İlçesi (11.09.2019). 
